\title{
The Perception of Management Support for Patient Safety After the Implementation of a System Change
}

Janice M. Smith

WVU, jmsmith3@mix.wvu.edu

Follow this and additional works at: https://researchrepository.wvu.edu/etd

Part of the Nursing Commons

\section{Recommended Citation}

Smith, Janice M., "The Perception of Management Support for Patient Safety After the Implementation of a System Change" (2019). Graduate Theses, Dissertations, and Problem Reports. 3877.

https://researchrepository.wvu.edu/etd/3877

This Dissertation is protected by copyright and/or related rights. It has been brought to you by the The Research Repository @ WVU with permission from the rights-holder(s). You are free to use this Dissertation in any way that is permitted by the copyright and related rights legislation that applies to your use. For other uses you must obtain permission from the rights-holder(s) directly, unless additional rights are indicated by a Creative Commons license in the record and/ or on the work itself. This Dissertation has been accepted for inclusion in WVU Graduate Theses, Dissertations, and Problem Reports collection by an authorized administrator of The Research Repository @ WVU.

For more information, please contact researchrepository@mail.wvu.edu. 
Janice M. Smith, MSN, RN, NNP-BC

The Perception of Management Support for Patient Safety After the

Implementation of a System Change

DNP Project submitted

to the School of Nursing

at West Virginia University

in partial fulfillment of the requirements for the degree of

Doctor of Nursing Practice

Theresa Cowan, DHED, ACNS BC, Chair

Alvita Nathaniel, Ph.D., APRN, FNP-BC, FAANP

Elaine A. Davis, Ed.D., R.N.

School of Nursing

Morgantown, West Virginia

2018

Keywords: Safety Culture, Safety Climate, Executive Leadership WalkRounds, Executive walk rounds, and Patient Safety

Copyright 2019 Janice M. Smith 


\begin{abstract}
The Perception of Management Support for Patient Safety After the Implementation of a System Change

Janice M. Smith
\end{abstract}

Problem Statement Leadership scores on the AHRQ Hospital Patient Safety Culture Survey at a 268 bed teaching, acute care, nonprofit, non-governmental hospital in the South Atlantic Region of the United states have been decreasing for the past seven years. In those years there has been no plan to improve the scores. Safety scores published for this facility on public websites are mediocre or poor.

Theoretical Framework The Plan-Do-Study-Act (PDSA) conceptual model for rapid cycle improvement served as a foundation for the project. The model supported the project well with a plan, do (test the plan), study (analyze the results), act (spread solution or do another test of change).

Methods A quasi-experimental one group pre and post-test study design was used. A modified AHRQ Survey was utilized with a purposeful sample. The posttest was compared to a survey completed before the implementation of the project.

Findings and Implications The implementation of Institute for Healthcare Improvement's Leadership WalkRrounds ${ }^{\mathrm{TM}}$ needed modified for this organization. Even though modified the effective evidence-based practice model was found to significantly improve the staff's perception of leadership's support for patient safety $(p=.0037)$. This appears to be a worthwhile practice and should not be overlooked to improve safety culture that to contributes to patient safety improvement. 


\section{Dedication}

I dedicate this work to my late parents William and Mary Elsie Lyons and late husband David Lee Smith as they always encouraged me to be a life-long learner and to do anything that inspired me and that I wanted to do. I also dedicate this to my children James C. Shook, Jr and MaryEllen D. Smith for their encouragement and support through this long and at times difficult journey. 


\section{Acknowledgements}

Thank you to each of you without whose help and encouragement along the way this journey would not have been possible.

- To my committee members - Theresa Cowan, DHEd, ACNS BC., Chair, Alvita Nathaniel, Ph.D., APRN, FNP-BC, FAANP, and Elaine A. Davis, Ed.D., R.N. My sincere thanks for their insight, guidance, and time during this project. I am especially grateful to Dr.

Cowan for keeping me on track, Alvita for her expertise in process, mentorship, encouragement and friendship and to Elaine for her research expertise and helping me get trough the IRB process. I could not have done this without each of them.

- To Scott Dean, Ph.D. - for his invaluable statistical support and guidance to bring the project to completion.

- To my work colleague - Mary Emmett, Ph.D. for her research expertise, ongoing support and feedback.

- To my family and high school girlfriends - for their love and support and tolerating my messy paper filled house and constant worry over "getting my work done". 


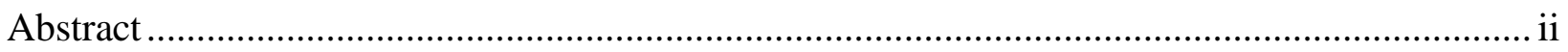

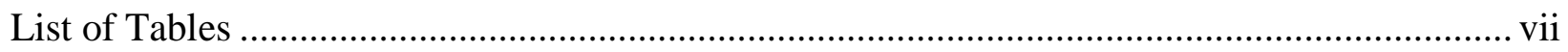

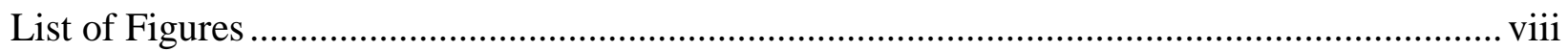

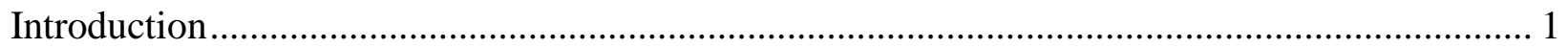

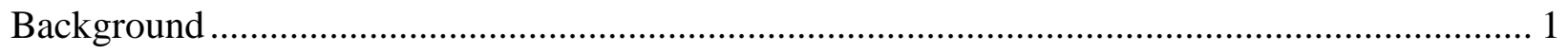

Statement of the Problem.............................................................................................. 9

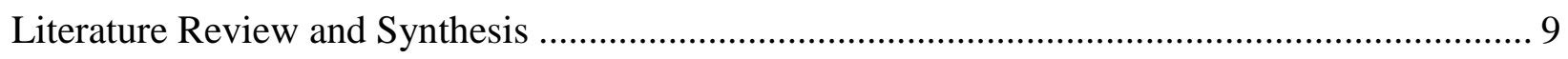

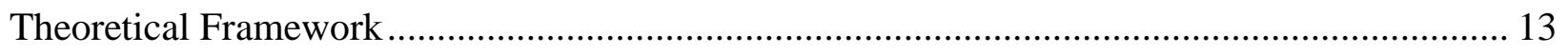

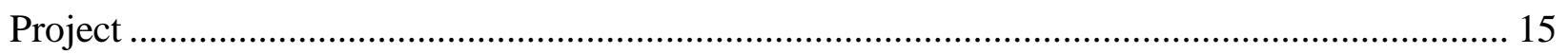

Evidence-Based Project …………………………………........................................ 15

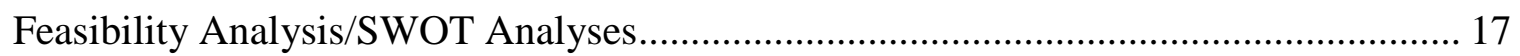

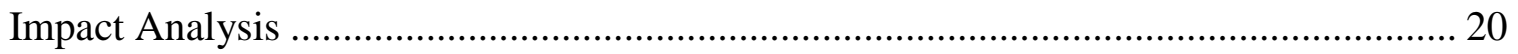

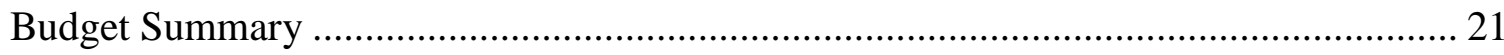

Decision Makers and Stake Holders ……………………........................................ 22

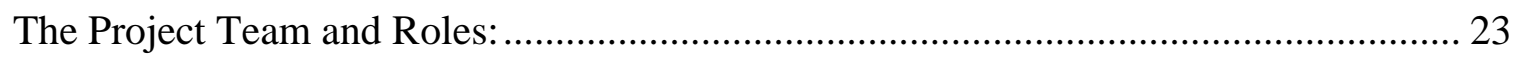

Congruence of Organization's Strategic Plan to Project ................................................ 24

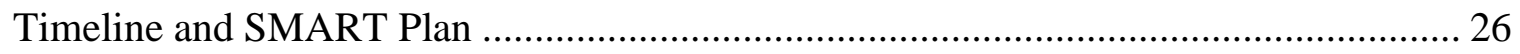

Measurable Project Objectives ................................................................................ 29

Method of Statistical Analysis ................................................................................... 39

Project Evaluation/Results ....................................................................................... 40

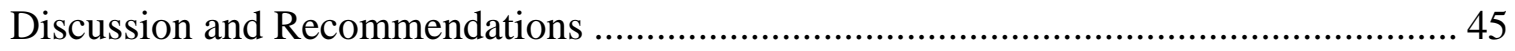

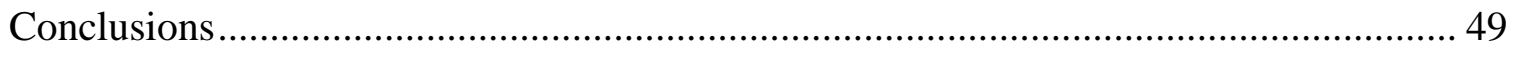

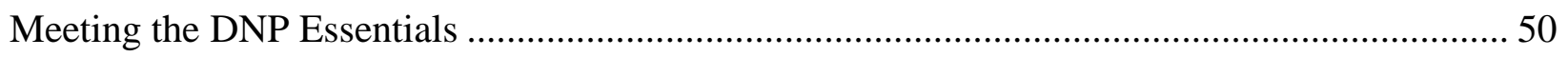




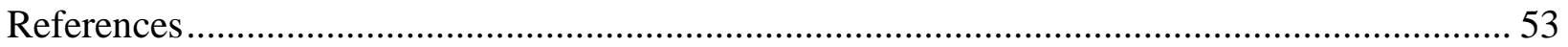

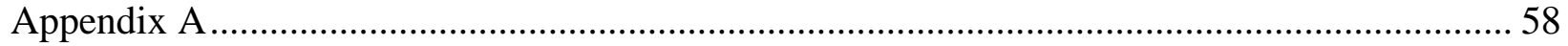

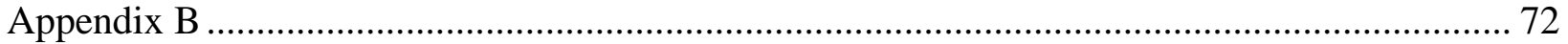

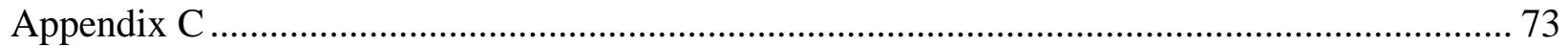

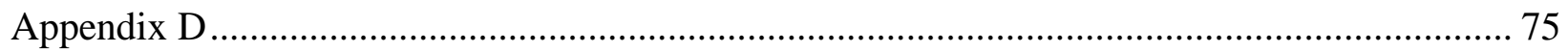

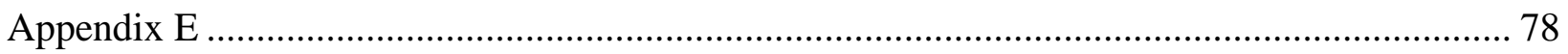

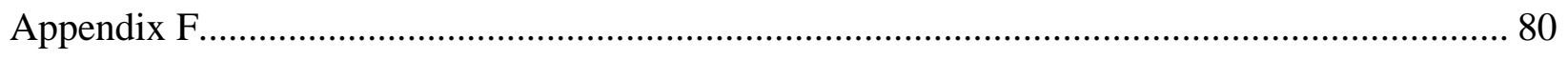

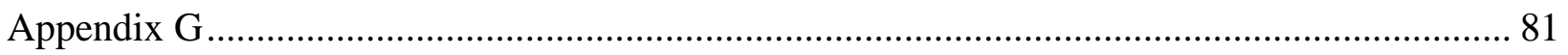




\section{List of Tables}

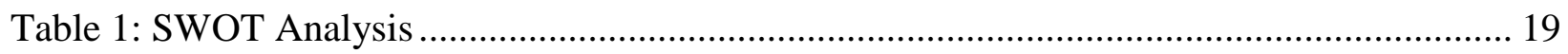

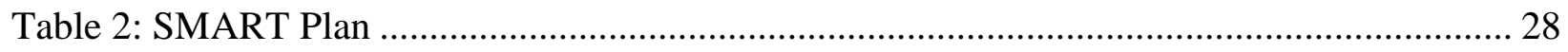

Table 3: Goals and Measurements of Success .................................................................. 31

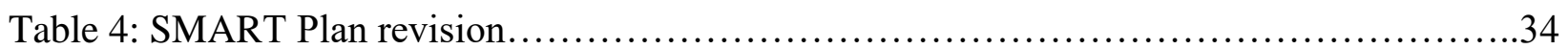




\section{List of Figures}

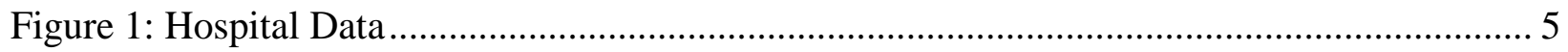

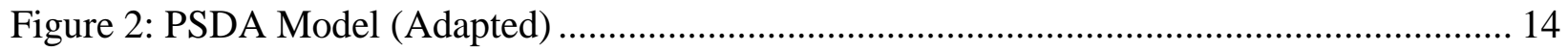

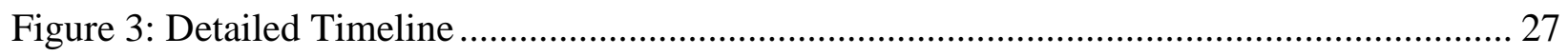




\section{Introduction}

At a 268 bed hospital in the South Atlantic region of the United States (U.S.), senior leadership scores on the Agency for Healthcare Research and Quality (AHRQ) Hospital Patient Safety Culture Survey have been decreasing for the past seven years. In those years, there has been no successful plan to improve the scores of senior leadership. The prior plan for senior leadership rounding was relegated to middle management. Safety scores published for this facility on public websites such as Medicare's Hospital Compare, Consumer Reports, and by the Group Leapfrog are mediocre or poor. The Leapfrog Group (2018) site uses national performance measures from their survey of hospitals if completed, the Centers for Medicare \& Medicaid Services (CMS), Association of Healthcare Research and Quality, the American Hospital Association, and the Centers for Disease Control and Prevention (CDC) to produce a hospital safety grade and to report on hospital acquired conditions.

Once the system problem was identified, a change project was designed and implemented. This project report provides a detailed description of the development, implementation, and evaluation of the project.

\section{Background}

The effects of poor safety culture within health care system are immense. In 1999 the Institute of Medicine's report To Err is Human noted that at least 43,000 to 98,000 people per year die or are harmed by medical errors in the U.S. (Kohn, Corrigan, \& Donaldson, 2001, p. 1). Adverse events were estimated to be the $3^{\text {rd }}$ leading cause of death in the U.S. in 2013 when deaths from medical error were calculated into the CDC common causes of deaths (Makary \& Daniel, 2016). These errors cost $\$ 36.6$ to $\$ 17$ billion per year and are approximately $4 \%$ of national health expenditures, higher than the direct and indirect costs of caring for people with 
HIV and AIDS (Kohn et al., 2001, p. 41). The World Health Organization (WHO) notes that $10 \%$ of people who receive health care in industrialized countries also suffer adverse events and preventable harm in hospitals (Donaldson \& Philip, 2004, p. 892). Great Britain, New Zealand, Australia, and Canada also report similar problems with preventable harm (Vincent, Neale, \& Woloshynowych, 2001; Davis et al., 2002; Barker et al., 2004).

In 2013, there were over eight million unintentional falls in the patient setting (Center for Disease Control and Prevention (CDC), 2015). Falls were the leading cause of nonfatal injury for all ages in the United States (CDC, 2013). There were 2.5 million nonfatal falls with injury, and 30,208 deaths from falls in 2013 (CDC, 2015). Injury increases cost for both the patient and hospital, increases the patient's length of stay, and leads to discharge to care facilities other than home discharges (Milisen, Staelens, \& Schwendimann, 2007). The costs associated with direct medical costs and lost productivity from falls were estimated to be $\$ 20.2$ billion in the year 2000 and this does not account for lost wages and housework, cost for nonmedical expenses, reduced quality of life, and functional activity (Stevens, Corso, Finkelstein, \& Miller, 2006).

The World Health Organization and others propose that to make the health system safer for patients and to prevent adverse events and preventable harm, organizational leaders must be committed to patient safety through action (Donaldson \& Philip, 2004, p. 892; Singer \& Vogus, 2013, p. 374-377). Leadership commitment is an important component of safety culture (Xuanye, Yanli, Hao, Pengli, \& Mingming, 2013). Zohr (2002) conducted a meta analytic review that showed the senior leader's role was critical in creating, changing and sustaining safety culture.

Safety culture is defined as the extent to which safety is prioritized both informally and formally by the organization and is the behavior of individuals and organizations based on their 
beliefs and values (Vogus, 2016; Weaver, Lubomksi, Wilson, Pfoh, \& Martinez, 2013; Xuanye, et al. 2013). Healthcare experts propose that a strong culture of patient safety is needed to reduce or eliminate harm (Institute for Healthcare Improvement, n.d.; Clancy, 2011; Vogus, 2016; Weaver, et al. 2013; American College of Healthcare Executives and National Patient Safety Foundation Lucian Leape Institute, 2017). It is important to measure patient safety culture, (Clancy, 2011; Xuanye et al., 2013;). Measuring safety culture fall under the leadership and the quality management system standards; are defined by regulatory agencies; and the standards are delegated to senior leaders. Regulators assess those standards and look for how the organization implements and measures the standards (Weaver, Lubomksi, Wilson, Pfoh, \& Martinez, 2013; The Joint Commission Resources, 2018). Hospitals across the country now use some type of safety culture measurement tool to meet the required measurement expectation. The Joint Commission leadership standard LD.03.01.01 specifies leaders create and maintain a culture of safety and quality throughout the hospital. Elements of performance for this standard require leaders to regularly evaluate the culture of safety using valid and reliable tools and to prioritize and implement changes identified by the evaluation (The Joint Commission Resources, 2018, p. PS27).

To build a culture of safety within hospitals, Leadership WalkRounds ${ }^{\mathrm{TM}}$ serves as a tool to promote patient safety and increase safety culture scores (Weaver et al., 2013; White, 2006, p. 55). The phrase Leadership WalkRounds ${ }^{\mathrm{TM}}$ is a formal trademark designating the walkround process designed by Dr. Allen Frankel, an anesthesiologist and the Director of Patient Safety at Partners HealthCare. The Leadership WalkRounds ${ }^{\mathrm{TM}}$ process consists of executive leaders (above the nurse manager level) meeting with front line staff on hospital units on a regular schedule to encourage discussion of current or potential threats to patient safety, support staff in 
addressing the threats, and provide feedback to staff when needed (Weaver et al., 2013; White, 2006, p. 55). The aim of Leadership WalkRounds ${ }^{\text {TM }}$ is to show leadership's commitment to patient safety, to develop trust, psychological safety, and support to front line staff (Weaver et al., 2013, p. 370). Experts in patient safety and the literature support the use of Leadership WalkRounds $^{\text {TM }}$ (Clancy, 2011; Weaver et al., 2013; White, 2006).

A plan was developed in 2005 at the organization to implement Leadership WalkRounds ${ }^{\mathrm{TM}}$ as a strategy for improvement of patient safety and to improve the leadership domain score on the patient safety culture survey. This strategy is a recommended improvement strategy by the Institute for Health Care Improvement (IHI). The IHI was founded in 1991 and has been part of the National Demonstration Project on Quality Improvement in Health Care since 1980. The IHI mission is to improve health and healthcare worldwide. IHI is an internationally recognized innovator, convener, and leader in healthcare improvement (Institute for Healthcare Improvement, n.d.).

As a former Patient Safety Specialist in a large hospital system, the author was responsible for measuring hospital patient safety culture. Beginning in 2007, this organization has utilized the Agency for Healthcare Research and Quality (AHRQ) Hospital Survey on Patient Safety Culture $(\mathcal{C}$ as a retrospective measurement of the patient safety culture. The survey has been completed at a minimum of every two years through January 2018 for a total of six times prior to the implementation of the current project. As depicted in Figure 1, each time the survey was completed, the results for the domain of leadership (which refers to senior leadership, defined as leaders above the nurse manager level) composite of management support for patient safety has been trending downward. In 2017, the domain composite was $30 \%$ below the benchmark. 
Figure 1: Hospital Data

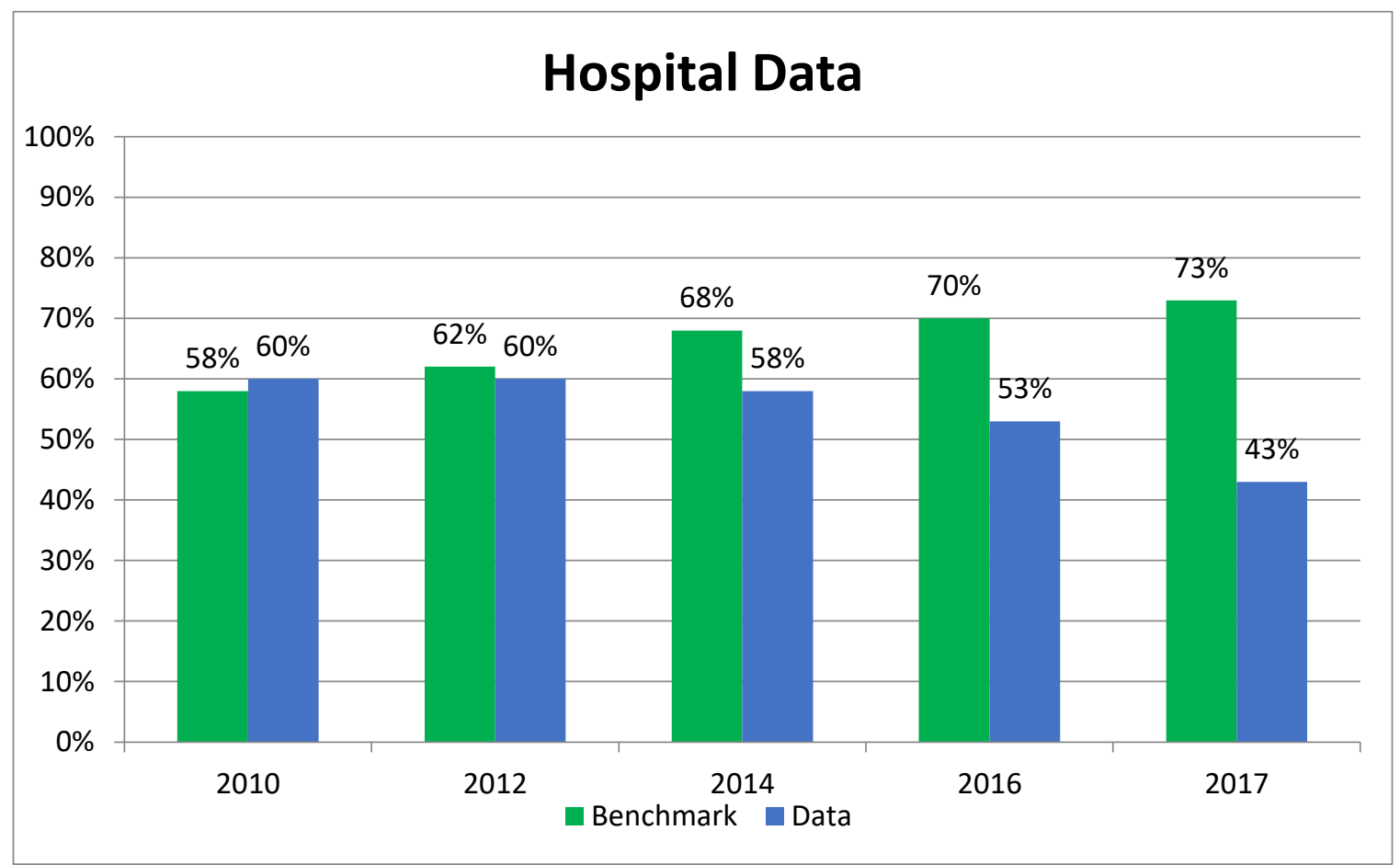

After the second AHRQ survey in 2010, senior leadership voiced the concern that staff was confusing senior leadership with middle management (nurse managers) so focus groups were requested for exploration of this concern. The research department for the organization conducted the focus groups and confirmed that the staff was able to correctly identify and differentiate between middle management and senior leadership.

In the ensuing years of using the same AHRQ survey since 2005, there was still no significant change in the domain scores for senior leadership and no action plan was put in place. While the plan was to implement Leadership WalkRounds ${ }^{\mathrm{TM}}$ in 2005, the IHI model was modified. Over time, the modified Leadership WalkRounds ${ }^{\mathrm{TM}}$ stopped occurring regularly or did not progress as planned. In 2010 there was a slight movement of the leadership domain 
scores above the benchmark when a few senior leaders were continuing to do Leadership WalkRounds $^{\mathrm{TM}}$ on an infrequent basis. In 2014, the Patient Safety Specialist in the Safety Department assessed that rounds had been relegated primarily to middle management within the first few years of implementation and senior leaders were not committed to performing the rounds. In fact, senior leaders seldom did rounds. Literature over time has continued to support senior leadership rounding as important to improvement of the safety culture (Donaldson \& Philip, 2004, p. 892; Frankel, 2004; Singer \& Vogus, 2013, p. 374-377; Singer \& Tucker, 2014; Sexton et al., 2017).

With middle management (nurse managers) performing the intended walkrounds, scores for their domain of supervisor/manager expectations and actions promoting safety on the survey steadily improved from 71\% positive in 2014 to 85\% positive in 2017 (Quality Improvement Department, 2010-2017). These scores measure how the supervisor/manager of a unit is performing on the AHRQ Hospital Survey on Patient Safety Culture survey. Senior leaders scores continued to decline and a score of $43 \%$ in 2017 was significantly below the benchmark mean of $73 \%$.

A debrief in 2017 was conducted by the author as part of the work role of Patient Safety Specialist. The purpose of the debrief was to share a unit's survey results and asses the staff's views about their unit's patient safety culture survey scores. Through staff sharing of ideas of what the scores meant to them and why the scores were high or low, it was determined that staff perception of why senior leadership scores were low was due to the belief that leaders at the senior level did not care about the staff's safety concerns. Staff members revealed that they had previously shared their concerns with the unit manager but the manager did not have resources or power to solve the safety concerns expressed. The group discussed the concept of Leadership 
WalkRounds ${ }^{\mathrm{TM}}$ and verbalized that they would like to see senior leadership perform Leadership WalkRounds ${ }^{\mathrm{TM}}$ so they could have that interaction and opportunity to share their concerns with them. During the debrief, a staff member stated, "They do not have a clue what we go through every day." Other staff members who desired the presence and interaction of senior management shared the perception.

Patient safety culture is important and a positive patient safety culture has been reported to enhance patient safety (Morello et al., 2013; McFadden et al., 2015). Safety scores published for this facility on public websites such as Medicare's Hospital Compare and by The Leapfrog Group are mediocre or poor (in the red). In the red means scores are below average compared to other like hospitals (The Leapfrog Group, 2018). In the fall of 2018 this hospital's overall safety score was a D on a scale of A to F. The hospital's score in 2016 and 2017 was a C. The poor grade was calculated from the five measures of preventable infections, problems with surgery, practices lacking that prevent errors, safety problems, and effective leadership (The Leapfrog Group, 2018). The 2018 poor score highlighted the following problems at this facility:

- Infections: Five infections are measured in the score 1. Methicillin resistant staphylococcus aureas, 2. clostridium difficile, 3. urinary tract, 4. blood, and infections after colon surgery. Four of the five were determined to be in the red (the score reflects the number of infections that actually happened compared to the number of expected infections for this hospital).

- Pressure ulcers: This score was in the red based on the number of patients that experienced a dangerous bed sore for every 1000 patients discharged.

- Falls: The score was in the red based on the number of times patients experienced falls or other types of trauma for every 1000 patients discharged. This hospital's score 
$=0.502$, best hospital score $=0.000$, worst hospital score $=1.747$, and average hospital score $=0.434$.

- Surgery problems: Seven measures make up these scores; three of the seven are in the red--mortality, collapsed lungs, and blood clots. Red scores included the number of patients that died for every 1000 people who had a serious treatable condition after surgery; collapsed lungs, based on the number of times patients experienced collapsed lungs for every 1000 people discharged; blood clots, based on the number of times patients experienced dangerous blood clots for every 1000 people what had surgery (the best hospital score $=1.21$, the average hospital score $=3.84$, this hospital's score $=4.73)$.

- Doctors, Nurses, and Hospital staff: These scores are based on 5 measures:

- Effective leaders to prevent errors: The hospital did not report any data for this measure, no score was calculated, and no secondary data was available.

- Enough qualified nurses: The hospital did not report any data for this measure, no score was calculated, and no secondary data was available.

- Specially trained doctors for ICU patients: The hospital's score is in the red. Based on 100 points, the best hospitals score is 100 , while the average hospital score is 49.7. The score of the hospital that is the focus of this project was 5--the worst hospital score.

- Communication with doctors: The hospital's score is in the red at 91, while the average hospital score is 91.16. The worst hospital score is 83 based on a scale of 0 to 100 . The score represents a comparison of patients' perspectives of how effectively physicians at this hospital communicated 
with patients relative to patients perspective at other hospitals; higher scores indicate more effective communication.

- Responsiveness of hospital staff: This score is based on patient feedback on how long it takes staff to respond to requests for help. Whereas the best hospital score is 94 , the hospital's score is in the red at 84.2 .

Medicare's Hospital Compare website provides the public with information about hospitals and allows one to compare performance of hospitals. A star rating of one to five stars is given to a hospital based on data on quality measures. This hospital's rating on Medicare's Hospital Compare (2019) is two stars.

\section{Statement of the Problem}

Leadership scores on the AHRQ Hospital Patient Safety Culture Survey have been decreasing at a 268 bed hospital in the South Atlantic region of the United States for the past seven years. In those years there has been no successful plan to improve the scores of senior leadership. The prior plan for senior leadership rounding was relegated to middle management.

\section{Literature Review and Synthesis}

To identify the best evidence regarding improving staff perceptions of management support for patient safety, an in-depth search of the literature was completed. The intent was to examine the evidence for interventions that show improvement in patient safety culture as a primary outcome and intervention goal.

Search terms used for the search were safety culture, safety climate, Leadership WalkRounds ${ }^{\mathrm{TM}}$, executive walk rounds, and patient safety. Electronic databases searched were The Cochrane Library, Academic Search Complete, the Cumulative Index to Nursing and Allied Health (CINAHL), PubMed and ProQuest. The initial search yielded 11, 809 hits. The search 
was narrowed to 428 articles by removing duplicates, limiting it to the years of $2000-2018$, the English language, application to hospitals, systematic reviews, randomized controlled trials in peer-reviewed journals, and applying the defined terms for this project. See Appendix A for the literature review table. Boolean search mode and snowballing was utilized. Total articles for this review were one systematic review with meta analysis, four systematic reviews and 2 cohort studies, a total of seven articles.

Two systematic reviews were found in the Database of Abstracts of Reviews of Effects (DARE) on The Cochrane Library site. DARE contains details of systematic reviews that evaluate the effects of healthcare interventions and the delivery and organization of health services. Reviews are quality assessed for inclusion in DARE and they are a key resource for busy clinicians in both healthcare policy and practice. DARE complements the Cochrane Database Systematic Reviews by identifying and including systematic reviews that have not been carried out by the Cochrane Collaboration (The Cochrane Library, n.d.).

The author and a nursing colleague of the author independently screened the articles identified using the Rapid Critical Appraisal of Systematic Reviews of Clinical Interventions/Treatments developed by Melnyk and Fineout-Overholt (2015, p. 547). Articles were abstracted by the primary reviewer, checked by the second reviewer, and then reviewed by the reviewers together.

The review of the literature provides a comprehensive background on the value of leadership engagement (Clay-Williams, Nosrati, Cunningham,Hillman, and Braithwaite (2014); Sammer, Lykens, Singh, and Mains (2010); Morello et al. (2013); McFadden, Stock, and Gowen (2015). Leadership WalkRounds ${ }^{\mathrm{TM}}$ was supported as a tool for improving safety culture scores and patient outcomes (Weaver et al. (2013); Morello et al. (2013); Singer and Tucker (2014); 
Sexton et al. (2017). There is support in the literature that shows there is improvement in patient outcomes, decrease in worker burnout, decrease employee turnover, decrease in hospital costs, and decrease in cost of employee turnover. Some cost reduction and other outcomes can be inferred by the findings.

Systematic reviews conducted by Clay-Williams et al. (2014), Weaver et al. (2013), Singer and Tucker (2014) all concluded that leadership engagement leads to a number of improvements. Four of the six studies in this systematic review conducted by Clay-Williams (2014) identified a decrease in detrimental hospital acquired conditions of vancomycin resistant e-coli and methicillin resistant staphylococcus aureus and the number of serious adverse events per 1000 adjusted patient days decreased. Weaver et al. (2013) found six of eleven studies reported patient outcomes and five of the six documented decrease in the length of stay, and rate of reported errors. Singer and Tucker's (2014) systematic review included a study that showed improvement in taking vital signs resulted in patient safety risk reduction due to earlier intervention to changes occurring. While this search did not specifically look for cost reductions, they could be inferred by decreased length of stay, improved pay for performance, and decreased litigation costs when safety risks are reduced.

Decrease in worker burnout was found with leadership walkrounds in Sexton et al.'s (2017) cohort survey and Weaver, et al. (2013) systematic review. Sexton, et al.'s (2017) crosssectional cohort survey of 31 hospitals with a $70.4 \%$ response rate found a strong pattern of response at both the respondent and work setting levels concluding that walk rounds with feedback was effective. Analysis of the quartiles with a threshold of $60 \%$ revealed that the first vs. second quartile t- tests were significantly different for burnout. The authors and data suggest that leadership walkrounds with feedback to those involved have better work environments with 
one metric being emotional exhaustion component of burnout. The systematic review by Weaver, et al. (2013) presented that two studies that also reported a reduction in burnout. There was no statistical data presented.

Decrease in employee turnover related to leadership walkrounds was found in two studies in the Weaver, et. al., (2013) systematic review. Strength of the evidence was low due to most studies being pre- and post-evaluations and low to moderate quality. No statistical analysis of the studies was included in the review.

Leadership walkrounds can also lead to cost reduction. Cost reduction with leadership walkrounds was reported in the systematic review conducted by Weaver, et. al., (2013). One study included in the systematic review found adjusted care cost was $\$ 24.01$ lower for the intervention work areas despite the length of stay adjustment at 0.19 days longer. There was no statistical significance in this reduction. It is also safe to infer that a decrease in employee turnover as reported by Weaver, et. al (2013) would reduce the cost of unnecessary recruitment, orientation, and training cost of new employees.

In the Weaver, et. al. (2013) systemic review, leadership walkrounds were identified as an effective safety intervention that can change staff perception of patient safety culture. These rounds are an interventional strategy that engages senior leadership above nurse managers directly with front-line staff with a goal of discussing current or potential threats to patient safety and to support front-line staff in addressing these threats. The aim is to show leadership commitment to safety, foster unit trust, and psychological safety and to provide support to the staff (Weaver, et al. 2013). The identified components of leadership walkrounds were shown to be effective with staff. Leadership walkrounds are difficult to compare across studies and time intervals because the structure of the studies vary. 
The review and the author's experience and expertise as a patient safety specialist defined the basis for the rationale of this project. While there are limitations in all the systematic reviews, the information gained from the reviews was of value in developing and implementing this project. Others' successes and experience was used to build an evidence-based project. This process assisted the author to meet the DNP essential of translating research into practice to improve outcomes as described by Melnyk and Fineout-Overholt (2015).

\section{Theoretical Framework}

The conceptual model that served as a foundation for the project was the Plan-DoStudy-Act (PDSA) model for rapid cycle improvement (Frankel, Haraden, Federico, and LenociEdwards, 2017). As illustrated in figure 2, the PDSA is an interactive, four-stage problemsolving model intended to structure the process of change within an organization. This framework asks three questions, what are we trying to do, how will we know that an improvement has been made, and what change can we make that will result in improvement. 
Figure 2: PSDA Model (Adapted)

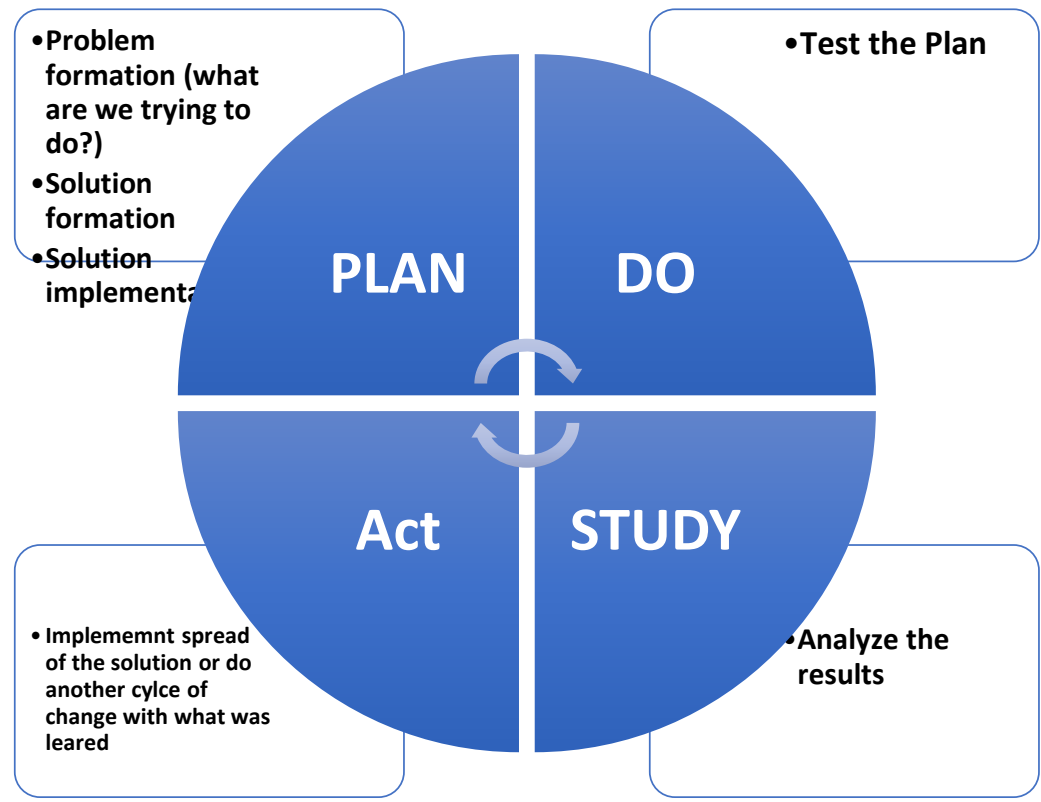

Adapted from (Frankel et al., 2017, p. 21)

The PDSA framework supported this project well by providing a framework for the project. In the plan stage a problem was identified, a solution for improvement was formulated in the form a change. The goals and aims in this project reflect what this author is trying to accomplish. In the do phase the plan for change was tested and measurement was performed to assess improvement. The act stage identified if the improvement was to be spread or another test of change was needed. The SMART plan presented in the project section of the paper reflected the Plan Do Study Act sections of the model. Support for use of this model comes from this author's experience using the model and this change model is used by the organization where the project was implemented. Experts support the PDSA model's use (White, 2006, p. 55; Frankel et al., 2017). 


\section{Project}

\section{Evidence-Based Project}

The problem was identified, a solution was formulated, the evidence-based practice of Leadership WalkRounds ${ }^{\mathrm{TM}}$ utilizing the PDSA model (as depicted in Figure 2) was implemented, and an evaluation was completed. Those who participated in the project included the Vice President of the hospital (representing executive leadership), the Assistant Administrator of the unit (representing executive leadership), the nurse manager, clinical management coordinator of the unit, the hospital's Director of Patient Safety, the author (who assumed the role of project manager), and front-line staff. Leadership WalkRounds were to be scheduled once per week on a selected unit by the VP with the project manager, the Assistant Administrator of the unit, and the Director of Patient Safety. During each round everyone in attendance were to be allowed the opportunity to speak freely and receive candid feedback about patient safety problems in the organization.

A description of the plan for implementation of Leadership WalkRounds ${ }^{\mathrm{TM}}$ included the following:

1. Manager of the unit will announce date time and place of the round when notified by the project manager, Vice President, Assistant Administrator, or the Director of Patient Safety and Risk Management.

2. The Vice President and the Assistant Administrator will conduct the Leadership WalkRound ${ }^{\mathrm{TM}}$.

3. Leadership WalkRounds ${ }^{\mathrm{TM}}$ will be completed a minimum of once per week, with no cancelations (if cancelations must reschedule within the week).

4. Leadership WalkRounds will be conduced on one unit at one hospital as 
described previously in the paper.

5. The format will be a conversation with minimum of 3-5 employees and will be held on the unit in the unit's conference room.

6. The script to open rounds was as follows: "We are moving to open communication and a blame free environment because we believe by doing so we can make your work environment safer for you and your patients. We are focusing on system and not individuals. The discussion we are having with you is confidential and for patient safety improvement, what we talk about will not go beyond this group unless you tell me there is a need for that. I may ask general questions to help you think of areas to which the questions might apply like medication errors, miscommunication including arguments, distractions, inefficiencies, invasive treatments, falls, protocols not followed, etc. Some questions. Can you think of any events in the past few days that have length of stay to be increased? Have there been any near misses? Have there been any incidents lately that you can think of where a patient has been harmed? What aspects of the environment might lead to harm? Is there anything we can do to prevent the next adverse event? Can you think of any way the system fails you on a consistent basis? How can leadership make it safer for you and your patients?" The above description of the plan to implement Leadership WalkRounds ${ }^{\mathrm{TM}}$ came from Frankel (2004).

There were two goals of this project. Goal 1 was to implement Leadership WalkRounds ${ }^{\mathrm{TM}}$ on a 35-bed medical surgical unit at a teaching, acute care, nonprofit, nongovernment 268 bed hospital in the South Atlantic region of the United States with an aim of 
documenting implementation to analyze feasibility for replication to another unit. Measurement of the success or the failure of the goal was determined to be the implementation of Leadership WalkRounds ${ }^{\mathrm{TM}}$ by noting how many rounds were completed vs. how many were planned. To analyze feasibility for replication of Leadership Walkrounds ${ }^{\mathrm{TM}}$ to another unit as the project progressed, information about each round was recorded in a log. Data in the log included the number of rounds completed, the number of times rounds were canceled and the reason for cancellation, the number of times rounds were rescheduled, feedback that was needed, feedback that was provided, and barriers that were identified.

Goal 2 was to improve staff members' perceptions of senior management support for patient safety. The plan was to measure the goal, utilizing a modified AHRQ Hospital Survey on Patient Safety pre- and post-implementation. The scores from the survey on the leadership domain, composite of management support for patient safety were compared to previous scores from prior to the intervention (May through June 2017). The design was quasi experimental with a comparison of pre-and post-implementation scores. The post implementation scores were compared to a survey completed before the implementation of this project. The following PICOT question guided the study: How do staff on one medical surgical unit at one hospital with Leadership WalkRounds ${ }^{\mathrm{TM}}$ perceive management support for patient safety over a threemonth period. Below are the descriptions of the project that include results of feasibility, SWOT, and impact analysis; description of the stakeholders, project team, and their roles; congruence with the organization's strategic goals; project timeline; data collection methods; results of the statistical analysis; and a discussion of the project.

\section{Feasibility Analysis/SWOT Analyses}

This project was determined to be feasible. Factors considered in assessing feasibility 
included the evidence base supporting the project, costs to the organization, time commitment of those involved in the project, and technical capabilities.

The evidence base support for the project came from the literature, those that participated in the project, and prior request from staff. Content of the evidence-based practice came from numerous years of published literature with success noted by others. Senior leaders, the Patient Safety Department, and unit management staff participated in the change team. Senior leaders, unit managers and staff were willing to participate in the implementation of the project. Senior leaders did the rounding and the Director of Patient Safety and Risk and the author documented in the log. There was a letter of support from senior leadership and verbal support from the Vice President of Medical Affairs/Patient Safety/ Risk Management/Quality Improvement. Staff requested Leadership WalkRounds in a debrief prior to implementation of the project.

The cost to the organization was more than one capital expenditure $(\$ 5,001.00)$ and was documented by a budget. See Appendix E for the detailed budget. The measurement tool (AHRQ Survey) was free online with only the cost of printing and handling. There were no copyright issues. There were no training costs identified as leaders in the organization have knowledge of the evidence-based practice model of Leadership WalkRounds ${ }^{\mathrm{TM}}$ and staff has experience using a similar survey tool over the past seven years. The project manager spent the most time on the project.

It was anticipated that there might be possible unacceptable demands placed on the staff if they were expected to attend rounds when staffing and workload did not permit. The strategy for preventing this was rounds were scheduled during periods of adequate staffing and when there was inadequate staffing the round was canceled and rescheduled.

Technical issues and limitations of the project were of the online survey system was not 
possible due to distrust of the organization voiced by several participants to the project manager. Staff verbalized that they do not trust that the organization cannot track the survey back to the individual if the survey is on the organization's server. There was no online opportunity available for documentation of log information as information technology (IT) service informed the author there was no time and budget allotted to assist the project manager to create an electronic data collection tool. It was determined that a log would be kept on paper by the Patient Safety and Risk Manager and the project manager for the rounds.

A SWOT analysis identified specific factors within the organization that would impact the success or failure of the project. Fallon, (2018) describes SWOT as a strategic planning tool used in business to identify the organization's strengths and weakness, internal and external threats to a proposed plan/change.

SWOT is an acronym for four elements with the $\mathrm{S}$ representing strengths, $\mathrm{W}$ representing weaknesses, O representing opportunities, and T representing threats. SWOT was the assessment tool used in an analysis planning process that allowed the author to overcome challenges and determine goals to pursue. The process helped to identify influencing forces influencing this project's strategy and action initiative. The analysis allowed the project manager to capitalize on the organization's strengths and opportunities and improve or eliminate threats and organization weaknesses. The primary objective of SWOT was to help develop a full awareness of all factors involved in a decision (Fallon, 2018). This SWOT analysis was completed during June 2018 from this author's experience with the organization and a debrief completed with staff in the author's former job role. Table 1, below, highlights the findings of the SWOT analysis. 


\begin{tabular}{|c|c|}
\hline Positives & Negatives \\
\hline $\begin{array}{l}\text { Internal Strengths } \\
\text { - } \quad \text { Leadership has the skill set to do LW* } \\
\text { - } \quad \text { LW not new to leadership, no new } \\
\text { learning required } \\
\text { - Staff and managers have had education on } \\
\text { LW } \\
\text { - Consultants have recommended this in the } \\
\text { - } \text { - Other successful projects in the } \\
\text { - } \text { organization have utilized rounding } \\
\text { - Minimal time involved } \\
\text { - } \text { Minimal resources involved } \\
\text { - Staff is committed to attend rounds } \\
\text { - Staff is committed to do the survey } \\
\text { - Patient Safety Department and Risk } \\
\text { - } \text { Fanagement support } \\
\text { wacus groups in the past have noted they } \\
\text { rounds }\end{array}$ & $\begin{array}{l}\text { Internal Weaknesses } \\
\text { - Leadership in the past has pushed LW to } \\
\text { middle management (nurse managers) } \\
\text { - } \quad \text { Executive leaders in the past have not } \\
\text { walked the talk } \\
\text { - } \quad \text { Executive leaders expect middle managers } \\
\text { to communicate for them } \\
\text { - Staff only hear from executive leadership } \\
\text { - } \text { Rhen something bad happens } \\
\text { - Requires commitment to the schedule } \\
\text { - } \text { rounding to hit all staff } \\
\text { log of technology to support survey and } \\
\text { Increased staff turnover }\end{array}$ \\
\hline $\begin{array}{l}\text { External Opportunities } \\
\text { - } \text { Meets regulation requirements } \\
\text { - } \text { Meets pay for performance standards } \\
\text { - } \text { Great pubic relations } \\
\text { - } \text { Good for recruitment of healthcare } \\
\text { - } \text { Oporkers } \\
\text { - Opens door to awards }\end{array}$ & $\begin{array}{l}\text { External Threats } \\
\text { - } \quad \text { Not meeting regulator leadership } \\
\text { - } \quad \text { Publishdards } \\
\text { - } \quad \text { Unable to obtain Magnet status } \\
\text { - } \quad \text { Decreased reimbursement from payors } \\
\text { - } \quad \text { Lost revenue } \\
\text { - Unable to maintain needed staffing levels } \\
\text { of healthcare workers }\end{array}$ \\
\hline
\end{tabular}

*LW refers to Leadership WalkRounds ${ }^{\mathrm{TM}}$

\section{Impact Analysis}

The scoring sources of Hospital Compare and The Leapfrog Group previously presented in this paper have a negative impact on this hospital and patients. The hospital loses payment from payers when patients have adverse events such as a fall with hip fracture or a hospital acquired pressure ulcer. The Leapfrog Group data presented previously in this paper documents there is a problem with infections, falls with injury and hospital acquired pressure ulcers, and 
other patient safety indicators. The score gives the organization a poor image and reflects that patients may be at risk for harm in this organization. Improving the scores would decrease regulatory concern, increase the organization's comfort with transparency, allow them to recruit highly qualified staff, improve patient safety outcomes, and increase the hospital's return on quality payment incentives. As a result, patients will be more likely to seek care at this organization and physicians will be more likely to refer patient to this hospital.

The organization is applying for Magnet Status. Magnet recognition is awarded to hospitals by the American Nurses' Credentialing Center (ANCC), an affiliate of the American Nurses Association. Hospitals must satisfy a set of criteria designed to measure the strengths and quality of nursing (The truth about nursing, 2016, p.1). As an employee of the hospital, the author was asked to contribute this project and its outcome to the Magnet status application. The project has assisted the organization to meet part of that application process.

\section{Budget Summary}

Categories used to develop the budget for the project were administrative, marketing, educational materials, hospitality, project supplies, and travel expense. The project manager's personal fund costs are $\$ 9769.96$ and organization contributions are $\$ 9575.71$.

The proposal called for no grant funds. The monetary burden was shared with the project manager and the organization for this project. The project manager donated time and travel to plan, implement, and evaluate the project. Organizational costs were marginal. See the itemized DNP Project Budget Proposal Appendix E for a detailed project budget.

This project allowed one to look at data in new ways and tell a compelling story. It was difficult to quantify cost savings to the organization due to the small sample and short duration of the project. Preventing one patient fall with injury in a hospital would save $\$ 34,294$ per fall 
("Falls cost U.S Hospitals, 2015). There is an awareness of the current state of staff perception of leadership via the current Hospital Survey on Patient Safety Culture Survey and past surveys.

\section{Market Analysis}

The project was a good example of supporting and meeting regulatory standards. There were no regulations that conflicted with the project. Regulatory agencies such as The Joint Commission (TJC) hospital accreditation agency for Medicare have a leadership standard that requires leaders to create and maintain a culture of safety and quality management throughout the hospital. The elements of performance for this standard require the hospital to measure the patient safety culture using valid and reliable tools. From that evaluation, leaders are guided to prioritize and implement changes identified by the evaluation. This leadership standard and its element of performance are congruent with this project. There is a risk to the organization if the regulators do not find patient safety culture improving over a period of time. Regulators look for assessment and leadership plans to improve patient safety culture scores. Regulators assess implementation of improvement plans (Leadership, 2018, p. PS 27).

\section{Decision Makers and Stake Holders}

The decision makers involved in this project were the Vice President, Assistant Administrator, Director of Patient Safety and Risk Management, project manager, nurse manager, clinical management coordinator, registered nurses, licensed practical nurses, health unit coordinators, and nursing assistants on the unit in which the project was implemented. Each member of this group made decisions in some way or another as they participated in the project.

Stakeholders have vested interest when they choose a hospital and expect safe, timely, efficient and cost-effective care. Leaders, patients, staff, regulators, community, investors, 
payers, and job seekers are seen as stakeholders. They are also decision makers. Patients decide to come or not to come to this hospital and trust they are going to get safe care at the facility of their choice. Staff decided whether or not to work on this unit or this facility, to participate in the rounds, to gain or lose something by participating, and they expect a safe environment to deliver care. Regulators expect leaders to oversee their organizations, decide what to focus surveys on and how to score the organization based on findings. Payers make the decision on what and how much to pay for a patient's care and choose what hospitals are in their network. The community expects an efficient and safe hospital. Investors expect wise use of their investments and good outcomes. Leaders are stakeholders as they own the process of patient safety in the organization and are responsible for performance improvement.

\section{The Project Team and Roles:}

The project team and individual roles were developed for each member. The team consisted of five organization leaders (executive and middle managers) and the project manager. Below is a list of team members with the defined role of each.

- Project manager (the author) manages the project and project implementation team, rounds with the Vice President, maintains and summarizes the logbook, handles all logistics of the project plan including handoff of the project at its completion.

- Vice President of the project hospital and member of project implementation team, sets the tone for rounding, rounds, provides feedback to staff, and implements or assures needed change from problems identified during rounds.

- Assistant Administrator of the project unit and member of the project implementation team, assists in setting the tone, rounds, provide feedback to staff, and assists Vice President to implement and assure needed change occurs.

- Director of Patient Safety and Risk Management, member of the project implementation team, rounds with the Assistant Administer, maintains logbook during their rounds.

- Nurse Manager of the project unit, member of the project implementation team, on the days of rounding assure staff able to attend rounds and helps to cover and manage staffing on the floor during the rounds 
- Clinical Management Coordinator of the project unit, member of the project implementation team, on the days of rounding assures staff is able to attend rounds and w helps to cover and manage staffing on the floor during the rounds.

- Vice President of Medical Affairs physician leader responsible for patient safety and quality in the organization, champion of the project, and provides input as necessary to overcome barriers.

Evidence of project support was in a letter from the Vice President of the hospital, (see Appendix D), active participation of decision makers and stakeholders, and verbal approval from the Vice President of Medical Affairs. There was open discussion with project implementation team members. Team members fulfilled their role as defined. Staff supported the project by attending rounds, speaking up during rounds, and completing the survey. The project did not start until IRB approval on October 15, 2019.

\section{Congruence of Organization's Strategic Plan to Project}

This project supported the mission, values, goals, and strategic plan of the organization. The mission of the organization is "Striving to provide the best health care to every patient, every day" (Mission Statement, 2018, p. 3). The intervention meets the mission statement as Leadership WalkRounds ${ }^{\mathrm{TM}}$ provide a forum for senior leaders to identify safety problems, gaps in performance and commit to improvement plans that enhance improvement in patient outcomes such as preventing falls and reflects striving to provide the best health care to every patient, every day. The organization has five vision pillars as follows:

- Best place to receive patient centered: This project focuses on patient-centered care through improvement of safety culture. With leadership involvement improvements can be made (Kohn, Corrigan, \& Donaldson, 2001, p. 15).

- Best place to work: Staff satisfaction is improved when care is safe, staff feel respected when they are listened to and have an opportunity to have a voice and participate in 
decision making (Sextion, etal.,2017). A systematic review by Weaver, Wilson, and Martinex, (2013) noted that two studies included in the review reported a reduction in burnout.

- Best place to practice medicine: Leadership WalkRounds ${ }^{\mathrm{TM}}$ is and effective way to provide communication and feedback. Feedback enhances work environment (Weaver, et al., 2013).

- Best place to learn: Life learning as staff and leaders learn from each other and learning is enhanced by innovative projects such as this one. Learning is supported by the organization by providing time to participate in projects such as this one.

- Best place to refer patients: When the work setting is a better place to deliver and receive care clinicians want to refer patients to this hospital.

In addition to the five pillars, the hospital has six core values (Health system continuous quality improvement, 2018, p. 9).

- Quality: This hospital defines quality as believing continuous improvement leads to performance excellence and that each employee has the responsibility to understand and act on the needs and expectations of patients and customers (Health system quality improvement, 2018, p. 9). This planned project by the author, an employee of the hospital, is taking responsibility to understand and act on a need of the organization.

- Service with compassion: Service is defined in the hospital's continuous quality improvement plan (2018) as providing care with concern, compassion, courtesy and skill and requires understanding and acting on needs of patients and customers. The project depicts the concern about declining leadership scores and reflects a sensitivity of the author to use their leadership skills to assist the hospital in improvement. 
- Respect: Respect is giving attention or consideration to others. Giving a forum for staff to speak up and being sensitive to staff's concern about being identified on their answers to the survey is respectful.

- Integrity: Integrity is defined as believe each person has dignity and are valued for the contribution each individual brings to the hospital (Health system continuous quality improvement, 2018). The core value of integrity is demonstrated through the project's commitment to the ethical principles of beneficence, non-maleficence, and confidentially-primarily through the prospect of improving health outcomes, protecting patients from unsafe conditions, and maintaining de-identified data collected during the project.

- Stewardship: The hospital's continuous quality improvement plan say it is committed to the wise use of our resources to achieve the mission and to meet the community's health care needs (Health system continuous quality improvement, 2018). Developing and maintaining a budget for the project is congruent with this value.

- Safety: Safety is defined as being devoted to the provision of a safe environment for patients, staff, medical staff, volunteers, residents, students and visitors. This project is devoted making an improvement that affects to outcome of patient safety.

\section{Timeline and SMART Plan}

A timeline and SMART plan were developed using the PDSA framework. The timeline and SMART plan were based on a twelve-month period and structured around the PICOT question. The Plan Do Study theoretical model structured the steps required for the implementation of this project. Implementation of the project was planned for a 3-month duration, beginning in October 1, 2018 and completed by December 31, 2018. See Figure 3, 
below, for a detailed timeline. The time line and SMART plan required modification due to IRB approval delay and a revised plan is presented in Table 4 SMART plan revision

Figure 3: Detailed Timeline

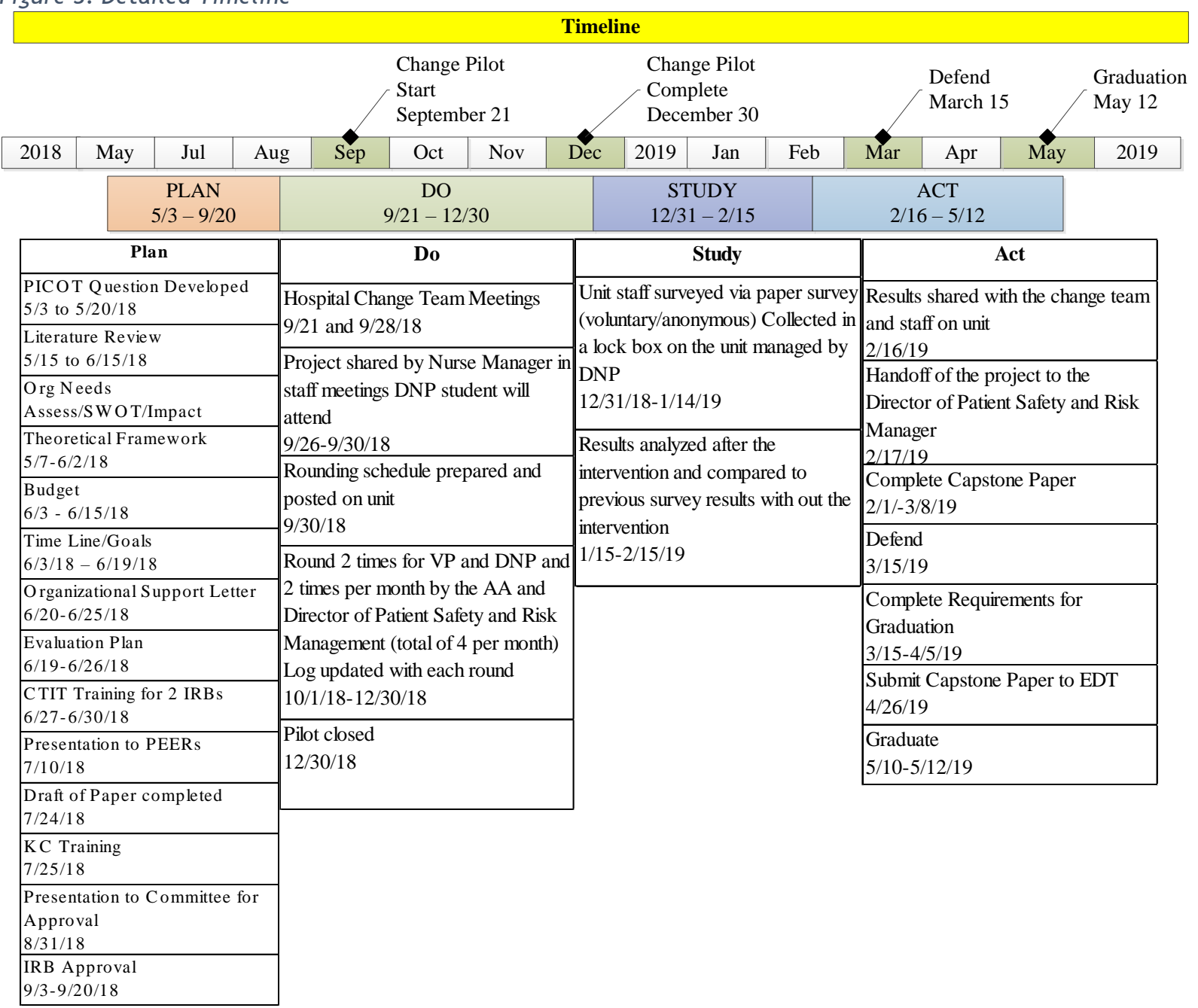

A SMART Plan was designed to guide the project. The plan is based on a format for SMART objectives, which was originally developed by Doran (1981). "SMART" stands for specific, measurable, achievable, relevant, and time-bound. It is a device for developing an organized action plan that gives structure to project management. See Table 2 for the detailed SMART plan. The SMART plan used the conceptual framework of the PDSA model and gave a foundation and a guide to work through the project in an organized and logical manner. The 
model is simple and used by many organizations to manage change. In the $\mathrm{P}=$ Plan part of the model the problem was identified, a solution was formulated, and solution was implemented.

The $\mathrm{D}=$ Do portion involved the test of the plan. The results were analyzed in the $\mathrm{S}=$ Study part of the plan and decision of implementation spread vs. do another cycle of change based on what was learned.

Table 2: SMART Plan

\begin{tabular}{|c|c|c|c|}
\hline Plan & Do & Study & Act \\
\hline $\begin{array}{c}\text { PICOT Question } \\
\text { Developed 5/3 to } \\
5 / 20 / 18\end{array}$ & $\begin{array}{c}\text { Hospital Change } \\
\text { Team Meetings } \\
\text { 9/21/18 } \\
\text { 9/28/18 } \\
\text { Project shared by } \\
\text { Nurse Manager in } \\
\text { staff meetings DNP } \\
\text { student will attend } \\
\text { 9/26 - 9/30/18 }\end{array}$ & $\begin{array}{c}\text { Unit staff surveyed via } \\
\text { paper survey } \\
\text { (voluntary/anonymous) } \\
\text { Collected in a lock box } \\
\text { on the unit managed by } \\
\text { DNP } \\
12 / 31 / 18-1 / 14 / 19\end{array}$ & $\begin{array}{l}\text { Results shared with } \\
\text { the change team and } \\
\text { staff on unit. } \\
2 / 16 / 19\end{array}$ \\
\hline $\begin{array}{l}\text { Literature Review } \\
5 / 15 \text { to } 6 / 15 / 18\end{array}$ & $\begin{array}{c}\text { Rounding Schedule } \\
\text { prepared and posted } \\
\text { on unit } \\
9 / 25 / 18\end{array}$ & $\begin{array}{l}\text { Results analyzed after } \\
\text { the intervention and } \\
\text { compared to previous } \\
\text { survey results with out } \\
\text { the intervention } \\
1 / 15-2 / 15 / 19\end{array}$ & $\begin{array}{l}\text { Handoff of the } \\
\text { project to the } \\
\text { Director of Patient } \\
\text { Safety and Risk } \\
\text { Manager } \\
\text { 2/17/19 }\end{array}$ \\
\hline $\begin{array}{c}\text { Org Needs } \\
\text { Assess/SWOT/Impact } \\
\text { 5/20-5/26/18 }\end{array}$ & $\begin{array}{l}\text { Round } 2 \text { times for } \\
\text { VP and DNP and } 2 \\
\text { times per Month by } \\
\text { the AA and Director } \\
\text { of Patient Safety and } \\
\text { Risk Management } \\
\text { (total of } 4 \text { per } \\
\text { month) } \\
\text { Log updated with } \\
\text { each round } \\
\text { 10/1/18 - 12/30/18 }\end{array}$ & & $\begin{array}{c}\text { Complete Capstone } \\
\text { Paper } \\
\text { 2/17 }-3 / 8 / 19\end{array}$ \\
\hline $\begin{array}{c}\text { Theoretical } \\
\text { Framework } \\
5 / 7-6 / 2 / 18\end{array}$ & $\begin{array}{c}\text { Pilot closed } \\
\text { 12/30/18 }\end{array}$ & & Defend $3 / 15 / 19$ \\
\hline Budget $6 / 3-6 / 15 / 18$ & & & $\begin{array}{l}\text { Complete } \\
\text { Requirements for } \\
\text { Graduation 3/15- }\end{array}$ \\
\hline
\end{tabular}




\begin{tabular}{|c|c|c|c|}
\hline Plan & Do & Study & Act \\
\hline Timeline/Goals 6/3/18 & & & $4 / 5 / 19$ \\
$-6 / 19 / 18$ & & & $\begin{array}{c}\text { Submit Capstone } \\
\text { Paper to EDT } \\
4 / 26 / 19\end{array}$ \\
\hline Organizational & & & Graduate \\
Support Letter & & $5 / 10-5 / 12 / 19$ \\
6/20-6/25/18 & & \\
\hline Evaluation Plan & & \\
6/19-6/26/18 & & \\
\hline CTIT Training for & & \\
IRBs & & \\
6/27-6/30/18 & & & \\
\hline Presentation to & & & \\
PEERs & & & \\
$7 / 10 / 18$ & & \\
\hline Draft of Paper & & & \\
completed & & \\
$7 / 24 / 18$ & & & \\
\hline KC Training & & & \\
$7 / 25 / 19$ & & \\
\hline Presentation to & & & \\
Committee for & & & \\
Approval & & & \\
$8 / 31 / 18$ & & & \\
\hline IRB Approval & & & \\
$9 / 3-9 / 20 / 18$ & & & \\
\hline
\end{tabular}

\section{Measurable Project Objectives}

There were two goals for this project. Goal 1 was to implement Leadership

WalkRounds ${ }^{\mathrm{TM}}$ on a 35 bed medical surgical unit at a teaching, acute care, nonprofit, non government 268 bed hospital in the South Atlantic region of the U.S. with an aim of documenting the implementation to analyze feasibility for replication to another unit. Measurement of this goal is that Leadership WalkRounds ${ }^{\mathrm{TM}}$ would be implemented and a logbook would be kept for collection of information related to implementation and feasibility. Twelve rounds were planned over a three-month period for staff to attend, identify problems and problem follow up completed and communication to staff. Another measurement tool was a 
logbook maintained by the project leader and the Director of Patient Safety and Risk Management. The log contained the number of rounds completed, when and how often, by whom, obstacles, reasons why Leadership WalkRounds were canceled, what problems were identified, feedback needed, and feedback given. Success would be noted if log recorded 12 rounds, logbook documented senior leadership lead the rounds, documented problems identified and what feedback was given to the staff, and the number of staff attending rounds. Goal 2 was to improve staff perception of senior management support for patient safety on one unit at this hospital as described previously. Perception was to be measured by a modified AHRQ Hospital Survey on Patient Safety Culture and scores on the leadership domain, composite of management support from patient safety compared to previous scores from prior to the intervention (May through June 2017), See Appendix F Modified Hospital Survey on Patient Safety: Management Support for Patient Safety. The Hospital Survey on Patient Safety is a tool that was developed and pilot tested in 1400 hospital employees from 21 hospitals in the U.S. by researchers after reviewing the literature pertaining to safety, accidents, medical error, error reporting, safety climate/culture, and organizational climate/culture, reviewing existing safety culture surveys, and conducting in-person and phone interviews with hospital staff (Sorra \& Nieva, 2004, p. 1). This tool has sound psychometric properties for the survey items and scales (Sorra \& Nieva, 2004, p. 2).

The Leadership domain items of the AHRQ survey is intended to measure senior leadership's managements support for patient safety and contains three items. The items are as follows: 1) Hospital management provides a work climate that promotes patient safety; 2) The actions of hospital management show that patient safety is a top priority; and 3) Hospital management seems interested in patient safety only after an adverse event happens. Chi-Square 
test for the analysis of change will be used. Success of this goal will be a p-value of $<0.05$ on the leadership domain.

The following measurable project goals focus on practice change within the system.

Table 3: Goals and Measurements of Success

\begin{tabular}{|c|c|}
\hline Goals & Measurements/Indicators of Success \\
\hline $\begin{array}{l}\text { 1. To implement Senior Executive } \\
\text { Leadership WalkRounds }{ }^{\mathrm{TM}} \text { on a } 35- \\
\text { bed medical surgical unit at a } \\
\text { teaching, nonprofit, non-government } \\
\text { hospital } 268 \text { bed hospital in the South } \\
\text { Atlantic Region of the U.S. } \\
\text { Aim: To document } \\
\text { Implementation of Senior } \\
\text { Executive Leadership } \\
\text { WalkRounds }{ }^{\mathrm{TM}} \text { to analyze } \\
\text { feasibility for replication to } \\
\text { another unit. }\end{array}$ & $\begin{array}{l}\text { - Aim logbook kept for data } \\
\text { collection to document } \\
\text { information (feasibility as } \\
\text { measured by: when/how often } \\
\text { they were completed, } \\
\text { obstacles, how often rounds } \\
\text { canceled and why). }\end{array}$ \\
\hline
\end{tabular}




\begin{tabular}{|c|l|}
\hline \multicolumn{1}{|c|}{ Goals } & \multicolumn{1}{c|}{ Measurements/Indicators of Success } \\
\hline $\begin{array}{c}\text { To improve staff perception of senior } \\
\text { leadership management support for } \\
\text { patient safety on a 35-bed medical }\end{array}$ & 2. Improved scores on the leadership domain \\
of the AHRQ Hospital Survey on Patient \\
$\begin{array}{c}\text { surgical unit at a teaching, nonprofit, } \\
\text { non-government 268 bed hospital in }\end{array}$ & scores completed in 2017 prior to the \\
the South Atlantic Region of the U.S. & \\
\hline
\end{tabular}




\section{Project Implementation}

The project centered on the implementation and evaluation of the evidenced-based practice of Leadership WalkRounds ${ }^{\mathrm{TM}}$. Careful planning of the project as described previously was started in the Spring of 2018 that included education on the part of the author; peer, hospital, and Institutional Review Board (IRB) approval. IRB approval was October 14, 2018. The project started October 31, 2018 and ended with handoff to senior leadership March 13, 2019.

The conception of the project started in the Spring of 2018 after the results of the hospital's AHRQ survey in 2017 failed to show improvement and the author in their formal job role of Patient Safety Specialist conducted a debrief with staff on a medical surgical unit of the hospital. Staff voiced concern about the hospital leadership not understanding their needs and that they wanted a forum with senior staff. The author had knowledge of the impact of leadership, what the literature stated about improving, what risk the hospital had from regulatory agencies, and how these scores impacted the hospital's patient safety and image outside the organization. Support of the project was sought and verbally obtained from the hospital and unit where a debrief of the 2017 Hospital Patient Safety Survey scores was completed.

During the summer of 2018 the author developed the PICOT question, completed the literature review, assessed the feasibility/SWOT/impact of the project on the organization, chose a theoretical framework, developed a timeline and goals for the project, obtained a letter of support from senior leadership, completed research training of Collaborative Institutional Training Initiative (CITI) for the IRB, presented the project to peers in the organization, completed Kuali training, chose a capstone committee, presented project to the committee and the IRB.

May 3 through June 19, 2017 the PICOT question was formulated; literature review 
completed; organizational needs assessment, SWOT analysis and impact analyses were completed; theoretical framework was followed to lay out the project; a budget was prepared; the timeline and goals were developed; and organization support was sought. During this time there was stress on the organization's part due to the results of the 2017 survey results. This encouraged this author to step into a leadership role and assist the organization in an improvement plan. The project concept was discussed with peers and a coalition of support was formed with the Vice President of the hospital, Vice President of Medical Affairs, Assistant Administrator of the debrief unit, Director of Patient Safety Risk Management, manager and clinical management coordinator of the debrief unit. Due to the identified value of this project, the Vice President was asked for a letter of support to complete the project on an agreed unit and an implementation team sought for the project. A letter of support was given and verbal approval to form the team. The evaluation plan was developed with the assistance of the organization's Research Department. A Capstone Committee was sought and formed of three trusted and highly qualified individuals. Training was completed for the IRBs. Training was challenging and time consuming but necessary learning. Capstone Committee approval was obtained to proceed to the IRB.

A SMART plan structured from the PDSA model guided the implementation as described in Table 4. The dates on the SMART plan as presented in Table 2 had to be modified due to delay in IRB approval that was due to a programming issue of the IRB's submission program. See the Table 4 SMART plan revision below. The original plan called for IRB approval between September 3, 2018 and September 20, 2018. IRB approval did not occur until October 15, 2018. The IRB delay required all of dates of the Do, Study and ACT phases of the SMART to change. This delay was a major frustration for the author and impacted the workflow in the research 
department of the organization.

Table 4: SMART Plan revision

\begin{tabular}{|c|c|c|c|}
\hline Plan & Do & Study & Act \\
\hline $\begin{array}{l}\text { PICOT Question } \\
\text { Developed } 5 / 3 \text { to } \\
5 / 20 / 18\end{array}$ & $\begin{array}{c}\text { Hospital Change } \\
\text { Team Meetings } \\
\text { 10/16/18 } \\
\text { 10/23/18 } \\
\text { Project shared by } \\
\text { Nurse Manager in } \\
\text { staff meetings DNP } \\
\text { student will attend } \\
\text { 10/23 - 10/31/18 }\end{array}$ & $\begin{array}{l}\text { Unit staff surveyed via } \\
\text { paper survey } \\
\text { (voluntary/anonymous) } \\
\text { Collected in an } \\
\text { envelope via U.S. Mail } \\
\text { managed by DNP } \\
\text { 2/1/19-2/14/19 }\end{array}$ & $\begin{array}{l}\text { Results shared with } \\
\text { the change team and } \\
\text { staff on unit. } \\
3 / 16 / 19\end{array}$ \\
\hline $\begin{array}{l}\text { Literature Review } \\
5 / 15 \text { to } 6 / 15 / 18\end{array}$ & $\begin{array}{c}\text { Rounding Schedule } \\
\text { prepared and posted } \\
\text { on unit } \\
10 / 31 / 18\end{array}$ & $\begin{array}{l}\text { Results analyzed after } \\
\text { the intervention and } \\
\text { compared to previous } \\
\text { survey results with out } \\
\text { the intervention } \\
2 / 25-3 / 08 / 19\end{array}$ & $\begin{array}{c}\text { Handoff of the } \\
\text { project to the Vice } \\
\text { President of the } \\
\text { Hospital, Director of } \\
\text { Patient Safety and } \\
\text { Risk, and Unit Nurse } \\
\text { Manager } \\
\text { 3/13/19 }\end{array}$ \\
\hline $\begin{array}{c}\text { Org Needs } \\
\text { Assess/SWOT/Impact } \\
\text { 5/20-5/26/18 }\end{array}$ & $\begin{array}{l}\text { Round } 2 \text { times for } \\
\text { VP and DNP and } 2 \\
\text { times per Month by } \\
\text { the AA and Director } \\
\text { of Patient Safety and } \\
\text { Risk Management } \\
\text { (total of } 4 \text { per } \\
\text { month) } \\
\text { Log updated with } \\
\text { each round } \\
10 / 31 / 18-1 / 31 / 19\end{array}$ & & $\begin{array}{c}\text { Complete Capstone } \\
\text { Paper } \\
\text { 3/13 }-3 / 22 / 19\end{array}$ \\
\hline $\begin{array}{c}\text { Theoretical } \\
\text { Framework } \\
\text { 5/7- 6/2/18 } \\
\end{array}$ & Pilot closed 1/31/19 & & Defend 4/5/19 \\
\hline Budget $6 / 3-6 / 15 / 18$ & & & $\begin{array}{c}\text { Complete } \\
\text { Requirements for } \\
\text { Graduation 4/5- } \\
4 / 26 / 19\end{array}$ \\
\hline $\begin{array}{c}\text { Timeline/Goals } 6 / 3 / 18 \\
-6 / 19 / 18\end{array}$ & & & $\begin{array}{c}\text { Submit Capstone } \\
\text { Paper to EDT } \\
4 / 23 / 19 \\
\end{array}$ \\
\hline $\begin{array}{l}\text { Organizational } \\
\text { Support Letter } \\
6 / 20-6 / 25 / 18 \\
\end{array}$ & & & $\begin{array}{c}\text { Graduate } \\
5 / 10-5 / 12 / 19\end{array}$ \\
\hline
\end{tabular}




\begin{tabular}{|c|l|l|l|}
\hline Plan & Do & Study & Act \\
\hline Evaluation Plan & & & \\
$6 / 19-6 / 26 / 18$ & & & \\
\hline CTIT Training for 2 & & & \\
IRBs & & & \\
$6 / 27-6 / 30 / 18$ & & & \\
\hline Presentation to & & \\
PEERs & & & \\
$7 / 10 / 18$ & & \\
\hline Draft of Paper & & & \\
completed & & & \\
$7 / 24 / 18$ & & \\
\hline KC Training & & & \\
$7 / 25 / 19$ & & \\
\hline Presentation to & & & \\
Committee for & & & \\
Approval & & & \\
$8 / 31 / 18$ & & & \\
\hline IRB Approval & & & \\
9/3- 10/15/18 & & & \\
\hline
\end{tabular}

The project team was formed and met as described previously in the project team and roles section of this paper. The team agreed to the project plan as presented and communication to staff was via staff meetings. Staff in the meetings verbalized excitement about the planned rounds. Schedule for rounds was posted. The posting had to be removed as round dates had to be revised due to leadership workload. Communication then occurred to staff by the nurse manager on the day a round was scheduled. There was no voiced displeasure of this change from posting.

Rounds occurred on the unit after IRB approval of the project during October 31, 2018 through January 31, 2019. The unit classroom was used for the rounds as staff participation was too large and unit too busy to hold the round in the hallway. A logbook was maintained of each round by the project manager and the Director of Patient Safety and Risk Management. During the period of rounding, project team communication was face to face, via phone, and via email.

Senior leadership did not do the rounding as planned and recommended by the Leadership WalkRound ${ }^{\mathrm{TM}}$ evidence-based practice of once per week. Rounding occurred 5 times 
during the 3-month period. The bar number was too high for this organization due to executive leadership workload.

The possible unacceptable demands that could have been placed on the staff during the project did not occur as the planned strategy for Leadership WalkRounds ${ }^{\mathrm{TM}}$ scheduled during periods of adequate staffing worked. Leadership WalkRounds ${ }^{\mathrm{TM}}$ were never canceled due to inadequate staffing. The project did not affect the workflow on the unit as traveling nurses, the nurse manager, and the clinical management coordinator staffed the unit during Leadership WalkRounds ${ }^{\mathrm{TM}}$. The time spent in Leadership WalkRounds ${ }^{\mathrm{TM}}$ was never more than 30 minutes.

The project added three tasks for staff: a meeting, signing a consent, and completing a short one-page survey. Meetings for the staff occurred five times during the project. Major time commitment was on the author as project manager, who led all aspects of the project.

The staffing plan during rounds assisted in the success of the project. Staff contributed to the success as staff attended Leadership WalkRounds ${ }^{\mathrm{TM}}$ and they spoke up. There were an average of 15 staff members attending each Leadership WalkRounds ${ }^{\mathrm{TM}}$ (range of 8-31). The author measured success with a modified AHRQ Hospital Survey on Patient Safety Culture (Appendix F).

Functional requirements were log keeping, supplies, and space to hold Leadership WalkRounds ${ }^{\mathrm{TM}}$ and project team meetings. The Director of Patient Safety and Risk Management and project manager maintained the logs. The project manager summarized the logbook, led the project team meetings, provided a written report for handoff, and led the handoff meeting on March 13, 2019.

Staffing during rounds and scheduling were other functional requirements. Staffing during Leadership WalkRounds ${ }^{\mathrm{TM}}$ was provided by the unit nurse manager, the unit clinical 
management coordinator, and traveling nurses. Commitment to meet all the requirements are noted in other sections of this paper.

There were privacy, confidentiality, and security issues. These were handled following IRB requirements. There was no identifying information on the surveys such as names. Surveys were placed in a pre-addressed, pre stamped envelope and mailed by the preparer via U.S. Mail to the research department affiliated with the organization. The author,with the assistance of the research department were the only persons to access, maintain, and handle the surveys. The consents for the study were signed by the project manager and staff. The staff completing the consent placed the consent in a separate envelope and sent to the project manager by interdepartmental hospital mail. Surveys and consents were never together after completion. Any paper data after collection has been kept in a locked file cabinet at the author's home. This author lives alone with a security system on the home. Only the author and a statistician in a research department have access to the raw data. Written reports did not contain identifying data.

\section{Data Collection Methods}

Survey data collection was managed by the project manager. The sample was purposeful as the author wanted to assure participants were integrated into the culture of the unit. Inclusion criteria included the following: Staff on the unit that work 20 hours per week or more, are not travelers (short term contract employees), and have worked on the unit greater than 6 months were eligible to take the survey. Eligible staff received from the author a consent for Participating in a Nursing Research Study (Appendix D, Consent for Participation in a Nursing Research Study) and a scantron survey sheet for survey completion (Appendix F, Modified Hospital Survey on Patient Safety Culture: Management Support for Patient Safety). A lock box was going to maintained on the unit for survey placement after completion, but the staff voiced concern about this method and the following method replaced the lock box. Each eligible staff 
member was provided two envelopes. One envelope was to return the consent back to the author by interdepartmental mail and the other was addressed and stamped with instructions to return the survey after completion to the organization's research department via U.S. Mail. Verbal reminders were given to the staff when the author made daily rounds on the unit during the data collection period of two weeks. E-mail reminders were sent to complete the survey every three days.

\section{Method of Statistical Analysis}

Statistical analysis was performed using SAS 9.3 (SAS Institute, Cary, NC). Chi-Square test used for the analysis of change in the three Patient Safety Culture items before and after the implementation of Leadership WalkRounds ${ }^{\mathrm{TM}}$. The three items were as follows: Q1. Hospital management provides a work climate that promotes patient safety; Q2. the action of hospital management show that patient safety is a top priority; and Q3. Hospital management seems interested in patient safety only after an adverse event happens. Q3 question is negatively worded. Favorable responses were defined as responses that were rated as Agree/Strongly Agree for positively worded questions (Q1, Q2), or Disagree/Strongly Disagree for negatively worded question (Q3). Background information was described by using frequencies. Any comparisons

made using background information questions were done by Chi-Square or Fisher's Exact test. A p-value of $<0.05$ was considered statistically significant. Turnover rate was considered with the before and after data.

Groups of less than five respondents were reported only with the entire group. Demographic data was reported with groups when there were at least 5 respondents. Response rate was calculated based on the number of eligible participants taking the survey and the eligible respondents returning the survey. Response rate of greater than $40 \%$ was considered 
representative of culture in the area.

Logbook information was reviewed by the project manager and summarized. A written report of the logbook information was included in the written report given to senior leaders during the handoff of the project.

Results reporting was to the hospital change team, unit staff if requested, author's capstone committee, and the West Virginia University Electronic Thesis and Dissertation program. Data is secure on a research server and only accessed by the statistician and the author. Data will be maintained for three years.

\section{Project Evaluation/Results}

Goal 1: To implement Senior Executive Leadership WalkRounds ${ }^{\mathrm{TM}}$ on a 35-bed medical surgical unit at a teaching, nonprofit, non-government 268 bed hospital in the South Atlantic Region of the U.S. with the aim to document the implementation to analyze feasibility for replication to another unit. Rounds were implemented as being completed in the logbook for a total of 5 times, $<50 \%$ completed. The plan was for 12 rounds to be completed over the threemonth period (12 rounds were planned). Rounds were canceled three times and not rescheduled due to competing priorities of the executive team members. This goal was not met as planned. Leadership rounds were not conducted 12 times. Staff attended the rounds with 15 to 32 staff members attending each round. The larger number was documented when a round was completed at the change of the shift, as there was more staff available at that time. Staff spoke freely and identified the problems of policy, security, and flow from the emergency room.

Three problem policies identified were the smoking, visitor, and care partner policies. The smoking policy allows patients to be off the unit too long and they are not available at times for physician rounds, tests, and nursing care as planned thus delaying their care. The visitor and care partner policy has no restriction of visitors. At times patients bring in the homeless they 
know as care partners to get them out of the weather. Feedback given to staff on policy concerns is they had been forwarded to the quality improvement committee and the policy and procedure committee for revision. A unit staff member volunteered and was approved to set on the policy and procedure committee. Feedback will continue to occur about these policies on a monthly basis during rounds.

There were two security issues identified. There is free access to the unit by anyone from a back elevator on the unit and there is an inability to lock doors to the unit when there is a safety risk from visitors. Feedback to the staff about security was the back elevator has been locked down to visitors as of November 15, 2018 and security doors have been ordered for this unit and will be installed in April 2019.

Patient flow from the emergency room causes delay in patient care for patients in the Emergency Room. When there are no beds available on the floor and patients must be held in the emergency room for an extended period of time admitting medications are not administered as ordered; food is not available for patients; there is no expectation/standard that admission tests ordered are initiated; and patients are put at risk when transported to the floor with ancillary staff when RN transport is needed. For the requested improvement in Emergency Room flow processes, feedback to staff was the Assistant Administrator of the Emergency room will be responsible for quality improvement of these problems. A unit staff member will work with the Assistant Administrator for resolution.

Even though 12 rounds were not completed, the project leader considers this strategy to have been successful in that staff attended the rounds, spoke up freely and identified problems, senior leadership assisted in the solution to two problems and is working with staff to solve other problems identified. Feedback to staff was provided with each round by senior leadership. 
Goal 2: To improve staff perception of senior management support for patient safety on one unit at this hospital as described previously. Perception was to be measured by a modified AHRQ Hospital Survey on Patient Safety Culture and scores on the leadership domain, composite of management support from patient safety and to compare current scores to previous scores from a survey completed in 2017. Statistical analysis was performed using SAS 9.3 (SAS Institute, Cary, NC). Chi-square test was used for the analysis of the change in the three Patient Safety Culture items before and after the implementation of Leadership WalkRounds ${ }^{\mathrm{TM}}$. One item is negatively worded. Favorable responses were defined as responses that were rated as Agree / Strongly Agree for positively worked questions (Q1, Q 2), or Disagree / Strongly Disagree for negatively worded question (Q3). Background information was described by using frequencies. Comparisons made using background information questions were done by ChiSquare or Fisher's Exact test. A p-value of $<0.05$ was considered statistically significant.

Goal 2 was to improve staff perception of senior leadership management support for patient safety on the same unit with the aim to compare current scores with previous scores completed in 2017. The goal was met in the overall score of the domain. The domain score improved when compared to the 2017 data to a $\mathrm{p}$ - value of $\mathrm{p}=0.0037$. Question 1, "Hospital management provides a work climate that promotes patient safety" resulted in a significant $\mathrm{p}$ value of $\mathrm{p}=0.0095$. Question 2, "The actions of hospital management show that patient safety is a top priority" resulted in a p value of 0.0521 . While not significant, it is moving in the right direction. Question 3, "Hospital management seems interested in patient safety only after and adverse event happens" (negative worded question) had a $p-$ value of $p=0.5188$. This was also not significant but is also moving in the right direction. See Table 5: Percent Favorable.

The response rate was calculated by dividing the number of completed surveys returned 
by the number of surveys distributed. For the project the response rate was $58 \%$ (N18) compared to $83 \%$ (N42) in 2017. See Table 5: Percent Favorable. The survey was open for 4 months in 2017 and for 2 weeks for this project.

Table 5: Percent Favorable Survey Responses

\section{Management Support for Patient Safety}

\section{RN O}

patient safety. (F1)

$53 \%$

$89 \%$

0.0095

2. The actions of hospital management show that patient safety is a top priority. (F8)

$50 \%$

$78 \%$

0.0521

3. Hospital management seems interested in patient safety only after an adverse event happens. (F9R)

Favorable - Agree/Strongly Agree for F1 and F8

Favorable - Strongly Disagree/Disagree for F9 
Table 6: Background

Data

Background

Information

\begin{tabular}{|c|c|c|c|c|}
\hline $\begin{array}{c}\text { Years at } \\
\text { organization }\end{array}$ & Frequency & Percent & $\begin{array}{l}\text { Cumulative } \\
\text { Frequency }\end{array}$ & $\begin{array}{c}\text { Cumulative } \\
\text { Percent }\end{array}$ \\
\hline $1-5 y r$ & 7 & 38.89 & 7 & 38.89 \\
\hline $6-10 y r$ & 5 & 27.78 & 12 & 66.67 \\
\hline $11-15 \mathrm{yr}$ & 1 & 5.56 & 13 & 72.22 \\
\hline $16-20 y r$ & 2 & 11.11 & 15 & 83.33 \\
\hline $21 \mathrm{yr}$ or more & 3 & 16.67 & 18 & 100 \\
\hline years_unit & Frequency & Percent & $\begin{array}{l}\text { Cumulative } \\
\text { Frequency }\end{array}$ & $\begin{array}{c}\text { Cumulative } \\
\text { Percent }\end{array}$ \\
\hline$<1 \mathrm{yr}$ & 2 & 11.11 & 2 & 11.11 \\
\hline $1-5 y r$ & 6 & 33.33 & 8 & 44.44 \\
\hline $6-10 y r$ & 4 & 22.22 & 12 & 66.67 \\
\hline $11-15 y r$ & 1 & 5.56 & 13 & 72.22 \\
\hline $16-20 y r$ & 2 & 11.11 & 15 & 83.33 \\
\hline $21 \mathrm{yr}$ or more & 3 & 16.67 & 18 & 100 \\
\hline $\begin{array}{l}\text { Hours worked per } \\
\text { week }\end{array}$ & Frequency & Percent & $\begin{array}{l}\text { Cumulative } \\
\text { Frequency }\end{array}$ & $\begin{array}{c}\text { Cumulative } \\
\text { Percent }\end{array}$ \\
\hline 20-39hrs & 11 & 64.71 & 11 & 64.71 \\
\hline 40-59hrs & 6 & 35.29 & 17 & 100 \\
\hline \multicolumn{5}{|c|}{ Frequency Missing = 1} \\
\hline job_category & Frequency & Percent & $\begin{array}{l}\text { Cumulative } \\
\text { Frequency }\end{array}$ & $\begin{array}{c}\text { Cumulative } \\
\text { Percent }\end{array}$ \\
\hline$<1 \mathrm{yr}$ & 3 & 16.67 & 3 & 16.67 \\
\hline $1-5 y r$ & 3 & 16.67 & 6 & 33.33 \\
\hline $6-10 y r$ & 6 & 33.33 & 12 & 66.67 \\
\hline $16-20 y r$ & 2 & 11.11 & 14 & 77.78 \\
\hline $21 \mathrm{yr}$ or more & 4 & 22.22 & 18 & 100 \\
\hline
\end{tabular}

Background information was not compared with the 2017 data because the information was not available. Frequency was used to present 2019 project background information See Table 6: Background Data above. 


\section{Discussion and Recommendations}

The project with a summary of the findings was handed off to senior leadership in a project team meeting on March 13, 2019. All in attendance verbalized the data was meaningful to them and they were pleased with the data. Senior leadership plans to continue to utilize this evidence-based practice with another cycle of improvement on this unit. Staff will complete the non-modified AHRQ survey in May 2019. This repeat survey will allow comparison with the scores documented from this project in order to further document the practice value to the hospital unit.

Regulators like to see data of this nature. The project data could be used if regulators ask to see a patient safety culture project. This project may meet the regulatory requirement of continuous performance improvement with measurement of safety culture. If the improvement does not continue, there is a model in place to refine and continue to test what drives improvement. Leadership is at risk with regulators when there is not improvement over time.

One might ask why revisit this evidence-based practice when it was unsuccessful in the past. People change, organizations change, knowledge of the practice grows, and failure adds knowledge. This evidence-based practice was of interest to author and as an expert clinician in patient safety comes the responsibility of risk taking. Other organizations have found a way to use this practice successfully and I had confidence this organization had the ability to be successful.

The Leapfrog Group and Hospital Compare publically report data previously presented in this paper are of concern to this author that patient safety is not improving in this organization and any former improvement that had been made has not been sustained. The low and continually decreasing scores on patient safety culture management support for patient safety is lacking an improvement strategy and a strategy was paramount to this author to consider. No 
patient safety outcomes were measured in this project because internal current data was not available to this author. Based on the organizational factor of culture influence and executive leadership importance on patient safety outcomes found in the literature review and synthesis, public reported data available, risk from regulators this author evaluated the implementation of this improvement strategy was assessed as warranted. On handoff of the project the project team leader recommended that internal patient safety outcome data be evaluated over time and as long as modified Leadership Walkrounds ${ }^{\mathrm{TM}}$ were occurring. The Leapfrog group and Hospital share data is also recommended to be assessed.

IHI's Leadership WalkRounds ${ }^{\mathrm{TM}}$ is an evidenced-based practice that can be utilized to improve patient safety culture scores but needed to be adapted to the organization's needs. With the need for adaption at this hospital the adaptation continues to make it difficult for researchers to compare outcomes of this evidence-based practice and will remain a challenge for researchers or clinicians when trying to compare studies. The Clay-Williams, et al, (2014) found that improved patient outcomes were observed for the studies when measurements were taken two years after the intervention and most studies usually gather data within 12 months of the intervention. These authors recognized culture is a slow changing phenomena and time is needed for outcome change to occur. Based on this finding, the author's lack of access of current patient safety outcomes, and posted public patient outcomes data no patient outcomes were measured with this study. New publically reported data was not available during this project for comparison with current data presented previously in this paper. Patient safety outcomes in future tests of change should continue to be monitored at this organization as a component if the model.

During the handoff from the author to senior leadership problems identified were: 
- the expectation of two rounds each per month was more than the executive leaders could handle;

- several problems identified that involved policy were taking longer to complete than expected;

- delays in improvement may undermine future progress for Leadership WalkRounds ${ }^{\mathrm{TM}}$; and

- the time commitment of doing one round per week for senior leadership was not manageable.

- financial resources may be needed for future improvements

- $\quad$ without a project team with a leader and team members with the same roles as in this project for another test of change may not be feasible

The nurse manager and clinical management coordinator on the unit recommended the expectation of four rounds per month be decreased to one to two rounds per month in the future. Due to the time commitment involved the project team leader recommends rounding be completed at least once per month and not less than once every other month as to not lose momentum of this project's success. Senior leadership plans to continue another test of change to this project and staff will be resurveyed on this hospital unit in May or June of 2019 by the Patient Safety Risk Management Department. For the resurvey the author recommends the same sample exclusions be utilized to allow comparison of the groups.

It is important to document the benefits of a project of this nature. Being able to document the benefits encourages sustaining change. Ten distinct benefits of the project were identified

- $\quad$ atient safety problems were identified; 
- $\quad$ suggestions were made for improvement;

- staff were given an opportunity to meet and talk with senior leaderhip;

- staff could see visible improvement from rounds such as an elevator being locked down with-in 15 days after the first round and security doors being installed for the unit with a completion date of April 12019 ;

- the process provided planned follow-up of issues identified ;

- the process gave the staff a voice with leaders that had the power and resources to address their concerns when complex;

- open communication was facilitated by senior leadership;

- $\quad$ satisfaction was verbally expressed by both senior leadership and staff; and

- there was onsite timely opportunities to receive feedback about ideas and whether or not changes can be made; and

- significant improvement in management support for patient safety was documented.

This project was labor intense for the author and without administrative support and a project leader another test of change may not be successful and improvement made from this project may not be sustained. Clinical champions are a common factor in successful system change (Clay-Williams, et al., 2014). The author (team leader of this project) sees the role played was that of a clinical champion.

A new budget for the test of change is needed. Cost of the project will decrease as the number of rounds will be less and staff time will decrease.

Sharing this paper through publication can add to the body of knowledge about this 
evidenced-based practice and can help others when making a decision to implement the practice. The need for modification of the practice will continue to add to the difficulty of researchers to compare studies of this nature because of these structure variables.

Recommendations during the handoff were to continue a modified Leadership WalkRounds $^{\mathrm{TM}}$ at one time per month for another test of change and to compare the results of this project when the organization resurvey's during the month of May in 2019. Completing another test of change would allow the leadership team to continue to evaluate the value of Leadership WalkRounds ${ }^{\mathrm{TM}}$.

Limitations of the study were the small sample size and the short length of time of the study. Selection bias was a threat to validity as this unit had a very poor survey score for the 2017 data. There also may have been a Hawthorne effect. There was no random sampling. Turnover rate on the unit in the study was $44 \%$ in 2018 . According to the Human Resource person assigned to this unit, the turnover was in the non-RN categories. The majority of the respondents in 2019 were in the category of the RN and longevity of a majority of the participants was extensive. There were possible unacceptable demands placed on the staff if they were expected to attend rounds when staffing and workload did not permit. This did not occur as the planned prevention strategies worked.

\section{Conclusions}

This capstone project significantly improved the leadership domain score of management support for patient safety and has potential to assist this hospital in multiple improvements. Improving this score has many advantages and as listed below. The project has assisted the organization to meet part of the application process for Magnet.

Improving leadership domain scores address: 
- a regulatory concern;

- increase the organization's comfort with transparency;

- allow recruitment of highly qualified staff;

- improve patient safety outcomes;

- increase staff satisfaction;

- improve the hospital's return on quality payment incentives; and

- allow the hospital to retain highly qualified staff.

This paper presents the documentation of the author's capstone project. Projects of this nature exemplify leadership, document the value of the DNP role and add to the body of knowledge.

\section{Meeting the DNP Essentials}

Graduation requirements include meeting the eight DNP essentials This project meets the essentials by the use of scientific inquiry, application of theory working with coalitions, leading a change project, adding to the knowledge base, providing policy makers with information to make decisions about policy, evaluating knowledge of an organization, and application of a project. Evidence-Based Practice is demonstrated as the project includes the evidence-based practice model of Leadership WalkRounds ${ }^{\mathrm{TM}}$ and a valid and reliable process measure of the AHRQ Survey.

Essential I: Scientific Underpinnings for Practice An evidenced based-practice approach of changing patient safety culture was revisited, planned, implemented, and evaluated using a small test of change. The project required research on the relationship between patient safety culture and evidenced based guidelines for changing patient safety culture. 
system assessment and problem identification the student developed a project that met the needs of the organization, the patient's it serves and evaluated the project outcome. The intervention was a problem focused initiative to improve the staff's perception of leadership support for patient safety with in a department and evaluated if the intervention could be spread system wide. The plan was purposeful, had integrated inputs, processes, outputs, feedback, and boundaries. There was purposeful action to achieve a shared goal. A budget was prepared, monitored, and evaluated. Cost effectiveness was analyzed accounting for risk from regulators.

\section{Essential III: Clinical Scholarship and Analytical Methods for Evidence-Based Practice}

Clinical scholarship was demonstrated by the scholarship of application of a pre and post test of survey responses after the implementation of the project. Evaluative comments were also solicited from leadership that conducted the Leadership WalkRounds ${ }^{\mathrm{TM}}$.

Essential IV: Information Systems/Technology and Patient Care Technology for Improvement and Transformation of Health Care Technology was utilized to do the literature search and to create tables and figure for the paper. A scantron system was utilized to do the survey and scanned into the spreadsheet for the SAS 4 statistical analysis program SAS 9.3 .

Essential V: Health Care Policy for Advocacy in Health Care Regulatory standards and health policy by Medicare, CMS and state hospital licensure boards were assessed and measuring safety culture is a requirement for organizations such as this one. These policies come under the leadership standards for the organization.

\section{Essential VI: Interprofessional Collaboration for Improving Patient and Population Health}

Outcomes This student lead a multidisciplinary project team that was brought together by the author to oversee this project. The team consisted of Nursing, Medicine, and Administration. The 
hospital's research department also supported this student with expertise and resources of a statistician. Communication and collaboration skills were utilized in the development and implementation of this project.

\section{Essential VII: Clinical Prevention and Population Health for Improving the Nation's}

Health The complex problem of poor leadership scores on patient safety directly effects patient safety. By evaluating and publishing the findings of this project related to this problem others could learn to improve.

Essential VIII: Advanced Nursing Practice This student developed a plan for implementation, implemented, and evaluated an evidence-based practice to improve a system weakness. This project required the development and staining therapeutic relationships and partnerships with others in the organization to facilitate the outcome. Leadership judgment was used, systems thinking were applied, and the student was accountable for the project Conceptual and analytical skills were used to identify links among practice, organizational, population, fiscal, and policy issues 


\section{References}

2018 Health System Strategic Plan. (2018). Unpublished manuscript.

American College of Healthcare Executives and NPSF Lucian Leape Institute. (2017). Leading a culture of safety: a Blueprint for success. Retrieved from npsf.org/page/culture of safety

Barker, G. R., Norton, P. G., Fintoft, V., Blias, R., Brown, A., Cox, J., ... Tamblyn, R. (2004, May 25). The Canadian adverse events study: the Incidence of adverse events among hospital patients in Canada. Canadian Medical Association Journal, 170, 1678-1686.

Botwinick, L., Bisognano, M., \& Haraden, C. (2006). Leadership guide to patient safety [IHI Innovation Series white paper]. Cambridge, Massachusetts: Institute for Healthcare Improvement.

Center for Disease Control National Center for Injury Prevention and Control. (2013). Webbased Injury Statistics Quary and Reporting System (WISQARS). Retrieved from http://www.cdc.gov/injury/wisquars

Center for Disease Control and Prevention. (2015). Falls among older adults: an overview (Issue brief). Washington, DC: Government Printing Office.

Clancy, C. M. (2011). New Research Highlights the Role of Patient Safety Culture and Safer Care. Journal of Nursing Care Quality, 26(3), 193-196.

Clay-Williams, R., Nosrati, H., Cunningham, F. C., Hillman, K., \& Braithwaite, J. (2014). Do large-scale hospital and system wide interventions improve patient outcomes A systematic review. BioMed Central Health Services Research, 14, 369.

Davis, P., Lay-Yee, R., Briant, R., Ali, W., Scott, A., \& Schug, S. (2002, December 13). Adverse events in New Zealand public hospitals I: Occurrence and impact. The New Zealand Medical Journal, 115(1167), 1-9. 
DiCuccio, M. H. (2015). The relationship between patient safety culture and patient outcomes: A systematic review. Journal of Patient Safety, 11(3), 135-142. Retrieved from https://psnet.ahrq.gov/resources/resource/27772/the-relationship-between-patient-safetyculture-and-patient-outcomes-a-systematic-review

Donaldson, L., \& Philip, P. (2004, December). Patient safety-a global priority [Editorial]. Bulletin of the World Health Organization, 82(12), 892-893.

Doran, G. T. (1981). "There's a S.M.A.R.T. way to write management's goals and objectives". Management Review. AMA FORUM. 70 (11): 35-36.

Fallon, N. (2018). SWOT analysis: What it is and when to use it. Retrieved from businessnewsdaily.com

Falls cost U.S. hospitals $\$ 34$ billion in direct medical costs (2015, April 22) Under the Dome, Retrieved from https:/www.johnshopkinssolutions.com/newsletters/falls-cost-u-shospitals-30-billion-in-direct-medical-costs/

Frankel, A. (2004). Patient Safety Leadership WalkRounds. Retrieved from http://www.ihi.org/resources/Pages/Tools/PatientSafetyLeadershipWalkrounds.aspx Frankel, A. (2004). Patient safety leadership walkRounds tm. Boston, Massachusetts: Institute for Healthcare Improvement.

Frankel, A., Haraden, C., Federico, F., \& Lenoci-Edwards, J. (2017). A framework for safe, reliable, and effective care [White paper]. Cambridge, MA : Institute for Healthcare Improvement and Safe \& Reliable Healthcare.

Health system continuous quality improvement. (2018). [Unpublished manuscript].

Institute for Healthcare Improvement. (n.d.). http:/www.ihi.org

Kohn, L. T., Corrigan, J. M., \& Donaldson, M. S. (Eds.). (2001). To err is human building a 
safer health system (3 ed.). Washington, DC: National Academy Press.

Leadership (LD) Standard LD.03.01.01 from "Patient Safety Systems" chapter in The Joint Commission: 2018 Comprehensive Accreditation Manual for Hospitals. Oak Brook, IL:Joint Commission Resources, 2019, p. 27, Retrieved from http://www.jointcommission.org/assets/1/6/PS_chapter_HAP_2018.pdf (Reprinted from Patient safety systems, by TJC, 2018)

Makary, M. A., \& Daniel, M. (2016, May 3). Medical error the third leading cause of death in the U.S.. British Medical Journal, 1-5. http://dx.doi.org/10.1136/bmj

McFadden, K. L., Stock, G. N., \& Gowen, III, C. R. (2015). Leadership, safety climate, and continuous quality improvement: Impact on process quality and patient safety . Health Care Manage Rev, 40(1), 24-43.

Melnyk, B. M., \& Fineout-Overholt, E. (2015). Evidence-bases Practice in Nursing \& Healthcare a guide to best practice (3 ed.). Philadelphia: Wolters Kluwer.

Medicare.gov|Hospital Compare https://www.medicare.gov/hospitalcompare/details.html?msrCd=prnt9grp1\&ID=510022

Milisen, K., Staelens, N., \& Schwendimann, R. (2007). Fall prediction in inpatients by bedside nurses using the St. Thomas's risk assessment tool in falling elderly inpatients (STRATIFY) instrument: multicenter study. Journal American Geriatric Society, 55, 725-733.

Morello, R. T., Lowthian, J. A., Barker, A. L., McGinnes, R., Dunt, D., \& Brand, C. (2013). Strategies for improving patient safety culture in hospitals: A systematic review. British Medical Journal, 22, 11-18.

Sammer, C. E., Lykens, K., Singh, K. P., \& Mains, D. A. (2010). What is patient safety culture?: 
A review of the literature. Journal of Nursing Scholarship, 42(2), 156-165.

Sexton, J. B., Adair, K. C., Leonard, M. W., Frankel, T. C., Peoulx, J., Watson, S. R., ... Schwendimann, R. (2017). Providing feedback following leadership walkrounds is associated with better patient safety culture, higher employee engagement, and lower burnout. British Medical Journal Quality and Safety, 0, 1-9.

Singer, S. J., \& Tucker, A. L. (2014). The evolving literature on safety WalkRounds: Emerging themes and practical messages. British Medical Journal Quality and Safety, 23, 789-800.

Singer, S. J., \& Vogus, T. J. (2013). Reducing hospital errors: interventions that build safety culture. The Annal Review of Public Health, 34, 373-396.

Sorra, J. S., \& Nieva, V. F. (2004). Hospital Survey on patient safety culture (AHRQ Publication No. 04-0041). Washington, DC: Government Printing Office.

Sorra J, Gray L, Streagle S, et al. AHRQ Hospital Survey on Patient Safety Culture: User's Guide. (Prepared by Westat, under Contract No. HHSA290201300003C). AHRQ Publication No. 15-0049-EF (Replaces 04-0041). Rockville, MD: Agency for Healthcare Research and Quality. January 2016. http;//www.ahrq.gov/professionals/quality-patient$\underline{\text { safety/patientsafetyculture/hospital/index.html }}$

Stevens, J. A., Corso, P. S., Finkelstein, E. A., \& Miller, T. R. (2006). The costs of fatal and nonfatal falls among older adults. Injury Prevention, 12, 290-295. http://dx.doi.org/10.1136/ip.2005.011015

The Cochran Library. (n.d.). http://www.cochranelibrary.com.www.libproxy.wvu.edu The Centers for Medicare \& Medicaid Services. (2019). Hospital Compare. Retrieved from https://www.medicare.gov/hospitalcompare/profile.html.

The Leapfrog Group. (2018). Hospital grade [Measurement Instrument]. Retrieved from 
http.//www.hospitalsafety

The Leapfrog Group. (2018). Leapfrog Hospital Safety Grade [Graph Illustration]. Retrieved from Http://www.hospitalsafety grade.org/your-hospitals-safety-grade

The truth about nursing [Newsgroup comment]. (2016, October, 16). Retrieved from www.truthaboutnursing.org/faq/magnet.html

Vincent, C., Neale, G., \& Woloshynowych, M. (2001, March 3). Adverse event in British hospital: Preliminary retrospective record review. British Medical Journal, 322, 517-519. http://dx.doi.org/

Vogus, T. J. (2016). Safety climate strength: a promising construct for safety research and practice. British Medical Journal Quality and Safety, 25, 649-652.

Weaver, S. J., Lubomksi, L. H., Wilson, R. F., Pfoh, E. R., \& Martinez, K. A. (2013, March 2013). Promoting a culture of safety as a patient safety strategy [A systematic review]. Annals of Internal Medicine, 158(5), 369-374.

Weaver, S. J., Lubomksi, L. H., Wilson, R. F., Pfoh, E. R., \& Martinez, K. A. (2013). Promoting a culture of safety as a patient safety strategy. Retrieved from http://annals.org/

White, S. V. (2006, March/April). Conference brief report: institute for healthcare improvement national forum on quality improvement in health care. Journal for Healthcare Quality, $28(2), 52-55$.

Xuanye, M., Yanli, N., Hao, C., Pengli, J., \& Mingming, Z. (2013). Literature review regarding patient safety culture. Journal of Evidence-Based Medicine, 6, 43-49.

Zohr, D. (2002). The effects of leadership dimensions, safety climate, and assigned priorities on minor injuries in work groups. Journal of Organizational Behavior, 23, 75-92. 


\section{Appendix A}

\section{Literature Review}

\begin{tabular}{|c|c|c|c|c|}
\hline Reference & Purpose & $\begin{array}{c}\text { Design/Site/Sampl } \\
\text { e/ } \\
\text { Limitations }\end{array}$ & $\begin{array}{c}\text { Intervention } \\
\text { / } \\
\text { Instrument }\end{array}$ & Results \\
\hline $\begin{array}{l}\text { Clay- } \\
\text { Williams, } \\
\text { Nosrati, } \\
\text { Cunningham, } \\
\text { Hillman, \& } \\
\text { Braithwaite, } \\
\text { 2014) } \\
\text { Focus on } \\
\text { organiza- } \\
\text { tional } \\
\text { determinants } \\
\text { of hospital } \\
\text { and system } \\
\text { wide } \\
\text { interventions, } \\
\text { outcome data } \\
\text { before and } \\
\text { after } \\
\text { implementatio } \\
\text { n of the } \\
\text { intervention }\end{array}$ & $\begin{array}{l}\text { To allow } \\
\text { generalizations } \\
\text { to be made on } \\
\text { the efficacy of } \\
\text { large scale } \\
\text { interventions } \\
\text { that could } \\
\text { inform future } \\
\text { implementatio } \\
\text { n of these } \\
\text { strategies for } \\
\text { improving } \\
\text { safety. } \\
\text { To identify } \\
\text { how } \\
\text { organizational } \\
\text { and cultural } \\
\text { factors mediate } \\
\text { or are } \\
\text { mediated by } \\
\text { hospital and } \\
\text { system wide } \\
\text { intervention } \\
\text { and assessing } \\
\text { the effect of } \\
\text { those factors } \\
\text { on patient } \\
\text { outcomes. }\end{array}$ & $\begin{array}{l}\text { Systematic Review } \\
\text { Sample } 6 \text { articles } \\
1 \text { non randomized } \\
\text { controlled trial } \\
3 \text { observational } \\
2 \text { controlled before } \\
\text { and after } \\
\text { Limited range of } \\
\text { studies in the } \\
\text { review } \\
\text { No intervention } \\
\text { appears in more } \\
\text { than one study or } \\
\text { setting } \\
\text { Lack of } \\
\text { standardization of } \\
\text { patient outcome } \\
\text { measures } \\
\text { Methodological } \\
\text { limitations: } \\
\text { Lack of control } \\
\text { groups } \\
\text { Reporting on one } \\
\text { lone organization } \\
\text { Lack of objective } \\
\text { performance } \\
\text { measures to verify }\end{array}$ & $\begin{array}{l}\text { Organization } \\
\text { al climate } \\
\text { intervention } \\
\text { associated } \\
\text { with } \\
\text { increased } \\
\text { hand- } \\
\text { washing and } \\
\text { decreased } \\
\text { nosocomial } \\
\text { infections } \\
\text { Impact of } \\
\text { converting to } \\
\text { and } \\
\text { electronic } \\
\text { health record } \\
\text { on culture } \\
\text { and quality } \\
\text { improvement } \\
\text { Outcomes } \\
\text { from the first } \\
2 \text { years of the } \\
\text { Australian } \\
\text { National } \\
\text { Hand } \\
\text { Hygiene } \\
\text { Institute } \\
\text { Large scale } \\
\text { organizationa } \\
1 \text { intervention } \\
\text { to improve }\end{array}$ & $\begin{array}{l}4 \text { studies found } \\
\text { significant patient } \\
\text { outcomes associated } \\
\text { with the intervention } \\
\text { Organizational } \\
\text { Factors: } \\
\text { organizational } \\
\text { culture/climate and } \\
\text { patient safety culture } \\
\text { overlapped } \\
\text { Organizational } \\
\text { determinants were } \\
\text { identified in all } 6 \\
\text { studies: } \\
\text { Staff morale \& } \\
\text { Organizational } \\
\text { climate, } \\
\text { organizational, } \\
\text { patient safety culture, } \\
\text { clinical and } \\
\text { organizational } \\
\text { leadership, education, } \\
\text { training, and } \\
\text { assessment, and } \\
\text { promotion and } \\
\text { awareness of the } \\
\text { intervention. } \\
\text { All } 6 \text { studies found } \\
\text { organizational } \\
\text { leadership, the } \\
\text { presence of clinical }\end{array}$ \\
\hline
\end{tabular}




\begin{tabular}{|c|c|c|c|c|}
\hline Reference & Purpose & $\begin{array}{c}\text { Design/Site/Sampl } \\
\text { e/ } \\
\text { Limitations }\end{array}$ & $\begin{array}{c}\text { Intervention } \\
\text { / } \\
\text { Instrument }\end{array}$ & Results \\
\hline & & $\begin{array}{l}\text { the improvement } \\
\text { Self selection for } \\
\text { program } \\
\text { implementation } \\
\text { (limits } \\
\text { generalisabilitiy) } \\
\text { Organizations that } \\
\text { volunteer may } \\
\text { differ from others } \\
\text { in a way that effect } \\
\text { implementation } \\
\text { success } \\
\text { Papers reflect those } \\
\text { perceptions of } \\
\text { those implementing }\end{array}$ & $\begin{array}{l}\text { patient safety } \\
\text { in } 4 \text { UK } \\
\text { hospitals } \\
\text { mixed } \\
\text { method } \\
\text { evaluation } \\
\text { Multiple } \\
\text { component } \\
\text { patient safety } \\
\text { intervention } \\
\text { in English } \\
\text { hospitals a } \\
\text { controlled } \\
\text { evaluation of } \\
2^{\text {nd }} \text { phase } \\
\text { Quality } \\
\text { improvement } \\
\text { initiative to } \\
\text { reduce } \\
\text { serious safety } \\
\text { events and } \\
\text { improve } \\
\text { patient safety } \\
\text { culture } \\
\text { Instruments } \\
\text { in the study } \\
\text { to measure } \\
\text { culture were } \\
\text { not } \\
\text { standardized }\end{array}$ & $\begin{array}{l}\text { intervention } \\
\text { champions to be } \\
\text { essential elements in } \\
\text { a successful } \\
\text { implementation. } \\
\text { All } 6 \text { studies had } \\
\text { dedicated financial } \\
\text { and managerial } \\
\text { resources for training } \\
\text { and education } \\
\text { associated with the } \\
\text { intervention }\end{array}$ \\
\hline $\begin{array}{l}\text { (Weaver, } \\
\text { Lubomksi, } \\
\text { Wilson, Pfoh, } \\
\text { \& Martinez, } \\
\text { 2013) } \\
\text { Promoting a } \\
\text { Culture of } \\
\text { Safety as a } \\
\text { Patient Safety } \\
\text { Strategy }\end{array}$ & $\begin{array}{l}\text { To identify } \\
\text { interventions } \\
\text { used to } \\
\text { promote safety } \\
\text { culture in } \\
\text { health care, } \\
\text { assess the } \\
\text { evidence for } \\
\text { effectiveness } \\
\text { in improving }\end{array}$ & $\begin{array}{l}\text { Systematic Review } \\
33 \text { studies in } 35 \\
\text { articles } \\
3 \text { concurrent } \\
\text { control } \\
\text { or pre-post with } \\
\text { concurrent } \\
\text { control }\end{array}$ & $\begin{array}{l}19 \text { studies } \\
\text { used Multi- } \\
\text { component } \\
\text { interventions } \\
\text { Thematic } \\
\text { analysis } \\
\text { identified } 3 \\
\text { broad } \\
\text { categories of }\end{array}$ & $\begin{array}{l}\text { No patient harms } \\
\text { were identified } \\
23 \text { of } 33 \text { studies } \\
\text { reported a } \\
\text { statistically } \\
\text { significant effect of } \\
\text { the intervention on } \\
\text { the overall safety } \\
\text { culture/climate score }\end{array}$ \\
\hline
\end{tabular}




\begin{tabular}{|c|c|c|c|c|}
\hline Reference & Purpose & $\begin{array}{c}\text { Design/Site/Sampl } \\
\text { e/ } \\
\text { Limitations }\end{array}$ & $\begin{array}{c}\text { Intervention } \\
\text { / } \\
\text { Instrument }\end{array}$ & Results \\
\hline & $\begin{array}{l}\text { culture and } \\
\text { patient } \\
\text { outcomes, } \\
\text { describe the } \\
\text { context, and } \\
\text { implementatio } \\
\text { n of the } \\
\text { interventions }\end{array}$ & $\begin{array}{l}\text { studies } \\
3 \text { time series } \\
2 \text { cluster } \\
\text { randomized } \\
\text { (RCTs) } \\
1 \text { quasi stepped } \\
\text { wedge } \\
\text { (most had pre-post } \\
\text { test designs and } \\
\text { small to moderate } \\
\text { sample size) } \\
\text { Clinical areas } \\
\text { studies included } \\
\text { medical surgical } \\
\text { units, ICUs, } \\
\text { perioperative, labor } \\
\& \text { delivery, \& } \\
\text { radiology } \\
\text { Sample sizes } \\
\text { ranged from } 5461 \\
\text { persons working in } \\
144 \text { units in a } \\
\text { single hospital and } \\
28 \text { in a single } \\
\text { hospital unit } \\
\text { Survey response } \\
\text { rates ranged from } \\
23 \% \text { to 100\% } \\
\text { Studies were } \\
\text { excluded if } \\
\text { interventions were } \\
\text { aimed at students } \\
\text { Qualitative Studies } \\
\text { were excluded } \\
\text { Articles for } \\
\text { inclusion were } \\
\text { reviewed by } 2\end{array}$ & $\begin{array}{l}\text { intervention } \\
\text { that emerged } \\
\text { in multiple } \\
\text { studies } \\
20 \text { studies } \\
\text { included } \\
\text { team training, } \\
8 \text { included } \\
\text { some form of } \\
\text { executive } \\
\text { walkrounds } \\
\text { and } 8 \text { used a } \\
\text { Compre- } \\
\text { hensive Unit } \\
\text { Based Safety } \\
\text { Program } \\
\text { (CUSP) (a } \\
\text { multifaceted } \\
\text { strategy for } \\
\text { culture } \\
\text { change } \\
\text { 21 studies } \\
\text { measured } \\
\text { culture with } \\
\text { the Safety } \\
\text { Attitudes } \\
\text { Questionnair } \\
\text { e } \\
\text { 10 used the } \\
\text { AHRQ } \\
\text { Hospital } \\
\text { Survey on } \\
\text { Patient } \\
\text { Safety } \\
2 \text { used the } \\
\text { Patient } \\
\text { Safety } \\
\text { Climate in } \\
\text { Organization }\end{array}$ & $\begin{array}{l}\text { Several reported } \\
\text { improvements in } \\
\text { team work climate } \\
\text { but found no } \\
\text { improvement in } \\
\text { safety culture/climate } \\
19 \text { studies reported } \\
\text { changes in patient } \\
\text { outcomes such as } \\
\text { harm (reduction } 5 \\
\text { studies) and clinician } \\
\text { outcomes such as } \\
\text { staff turnover or } \\
\text { burnout ( } 2 \text { reporting a } \\
\text { decrease in turnover) } \\
1 \text { study with the } \\
\text { implementation of } \\
\text { team training found } \\
\text { the weighted patient } \\
\text { harm score decreased } \\
\text { by } 37 \% \text { compared to } \\
\text { the control unit that } \\
\text { had an increase of } \\
43 \% \text { (p=<0.05) }\end{array}$ \\
\hline
\end{tabular}




\begin{tabular}{|c|c|c|c|c|}
\hline Reference & Purpose & $\begin{array}{c}\text { Design/Site/Sampl } \\
\text { e/ } \\
\text { Limitations } \\
\end{array}$ & $\begin{array}{c}\text { Intervention } \\
\text { / } \\
\text { Instrument }\end{array}$ & Results \\
\hline & & $\begin{array}{l}\text { reviewers } \\
\text { Organizations were } \\
\text { different } 4 \\
\text { community } \\
\text { hospitals, } 13 \\
\text { academic medical } \\
\text { centers, } 6 \text { a mix of } \\
\text { community/academ } \\
\text { ic } \\
1 \text { faith based } \\
\text { hospital } \\
\text { Differed in the } \\
\text { level of leadership } \\
\text { support and } \\
\text { engagement } \\
\text { supported } \\
\text { Few studies } \\
\text { examined potential } \\
\text { variation in } \\
\text { perception of safety } \\
\text { culture by care } \\
\text { provider type } \\
\text { Cannot be } \\
\text { generalized beyond } \\
\text { patient care settings } \\
\text { as only acute care } \\
\text { setting as included } \\
\text { the effectiveness is } \\
\text { not well suited to } \\
\text { assessing the } \\
\text { Possible } \\
\text { publication bias } \\
\text { and selective } \\
\text { reporting of } \\
\text { positive findings } \\
\end{array}$ & s Survey & \\
\hline
\end{tabular}




\begin{tabular}{|c|c|c|c|c|}
\hline Reference & Purpose & $\begin{array}{c}\text { Design/Site/Sampl } \\
\text { e/ } \\
\text { Limitations }\end{array}$ & $\begin{array}{c}\text { Intervention } \\
\text { / } \\
\text { Instrument }\end{array}$ & Results \\
\hline & & $\begin{array}{l}\text { effectiveness of } \\
\text { quasi experimental } \\
\text { design conducted at } \\
\text { a unit level and } \\
\text { could have } \\
\text { produced } \\
\text { systematic bias }\end{array}$ & & \\
\hline $\begin{array}{l}\text { (Sammer, } \\
\text { Lykens, } \\
\text { Singh, \& } \\
\text { Mains, 2010) } \\
\text { What is } \\
\text { patient safety } \\
\text { culture: A } \\
\text { review of the } \\
\text { literature }\end{array}$ & $\begin{array}{l}\text { To organize } \\
\text { the properties } \\
\text { of safety } \\
\text { culture address } \\
\text { by many } \\
\text { studies and to } \\
\text { develop a } \\
\text { conceptual } \\
\text { culture of } \\
\text { safety model }\end{array}$ & $\begin{array}{l}\text { Comprhensive } \\
\text { literature review } \\
\text { using meta analysis } \\
\text { Aim to develop a } \\
\text { typology of patient } \\
\text { safety culture } \\
\text { literature and } \\
\text { identify the key } \\
\text { concepts of patient } \\
\text { safety culture. } \\
\text { To authors agreed } \\
\text { to the grouping of } \\
\text { the concepts into } \\
\text { categories } \\
38 \text { studies }\end{array}$ & & $\begin{array}{l}\text { Identified a broad } \\
\text { range of patient } \\
\text { safety properties and } \\
\text { organized them into } 7 \\
\text { subcultures. } \\
\text { 1. Leadership } \\
\text { 2. Teamwork } \\
\text { 3. Evidence- } \\
\text { based } \\
\text { 4. Communicati } \\
\text { on } \\
\text { 5. Learning } \\
\text { 6. Just } \\
\text { 7. Patient- } \\
\text { centered }\end{array}$ \\
\hline $\begin{array}{l}\text { (Singer \& } \\
\text { Tucker, 2014) } \\
\text { The evolving } \\
\text { literature on } \\
\text { safety } \\
\text { WalkRounds: } \\
\text { emerging } \\
\text { themes and } \\
\text { practical } \\
\text { messages }\end{array}$ & $\begin{array}{l}\text { To review in } \\
\text { detail what has } \\
\text { been learned } \\
\text { so far about } \\
\text { leadership } \\
\text { walkrounds } \\
\text { and how } \\
\text { managers can } \\
\text { successfully } \\
\text { implement } \\
\text { these in their } \\
\text { organization }\end{array}$ & $\begin{array}{l}\text { Systematic Review } \\
43 \text { studies } \\
\text { Authors each } \\
\text { reviewed the papers } \\
\text { and assigned each } \\
\text { paper a theme \& } \\
\text { noted the findings } \\
\text { Most papers were } \\
\text { qualitative from } \\
\text { self selected } \\
\text { implementation of } \\
\text { rounds in a single } \\
\text { or a small number } \\
\text { of hospitals }\end{array}$ & & $\begin{array}{l}\text { 33/43 papers } \\
\text { reviewed reported a } \\
\text { positive impact on } \\
\text { their organizations } \\
\text { Demonstrated proof } \\
\text { of concept: } \\
\text { It is feasible for } \\
\text { senior leaders to } \\
\text { implement and } \\
\text { maintain rounds, } \\
\text { enable them to ID } \\
\text { meaningful safety } \\
\text { concerns, and to act } \\
\text { on those concerns. }\end{array}$ \\
\hline
\end{tabular}




\begin{tabular}{|c|c|c|c|c|}
\hline Reference & Purpose & $\begin{array}{c}\text { Design/Site/Sampl } \\
\text { e/ } \\
\text { Limitations } \\
\end{array}$ & $\begin{array}{c}\text { Intervention } \\
\text { / } \\
\text { Instrument }\end{array}$ & Results \\
\hline & & $\begin{array}{l}\text { Randomization was } \\
\text { lacking in most. } \\
\text { Few studies had } \\
\text { objective measures } \\
\text { They found no } \\
\text { studies that } \\
\text { collected financial } \\
\text { costs }\end{array}$ & & $\begin{array}{l}\text { Were able to } \\
\text { implement rounds } \\
\text { Impacts were on } \\
\text { senior managers' } \\
\text { belief and problem } \\
\text { solving activities: } \\
\text { Increased senior } \\
\text { managers' support } \\
\text { for patient safety } \\
\text { improvement efforts: } \\
\text { Enabled the } \\
\text { identification and } \\
\text { elimination of safety } \\
\text { hazards; } \\
\text { Improvement of } \\
\text { hospital efficiency; } \\
\text { enable leaders to } \\
\text { demonstrate safety } \\
\text { was a priority: } \\
\text { Front line staff felt } \\
\text { more willing to be } \\
\text { open about safety } \\
\text { issues; felt more } \\
\text { recognized; staff } \\
\text { morale improved } \\
\text { 14 papers empirically } \\
\text { examined the effect } \\
\text { of safety rounds } \\
\text { using safety } \\
\text { culture/climate } \\
\text { survey or } \\
\text { safety/quality } \\
\text { performance } \\
\text { measures. } 8 \text { of those } \\
\text { reported positive } \\
\text { outcomes that } \\
\text { stemmed from rounds } \\
\text { such as an improved } \\
\text { perceptions of }\end{array}$ \\
\hline
\end{tabular}




\begin{tabular}{|c|c|c|c|c|}
\hline Reference & Purpose & $\begin{array}{c}\text { Design/Site/Sampl } \\
\text { e/ } \\
\text { Limitations } \\
\end{array}$ & $\begin{array}{c}\text { Intervention } \\
\text { / } \\
\text { Instrument }\end{array}$ & Results \\
\hline & & & & $\begin{array}{l}\text { cluture/climate; ID } \\
\text { more adverse events; } \\
\text { Some studies did not } \\
\text { show positive results } \\
\text { (3) with rigorous } \\
\text { methods (2 } \\
\text { experimental } \\
\text { controlled studies } \\
\text { found safety climate } \\
\text { and perceived } \\
\text { performance } \\
\text { improvement one in } \\
\text { Veterans Health } \\
\text { Administration and } \\
\text { one in the private } \\
\text { sector in in } \\
\text { randomally assigned } \\
\text { intervention units) } 1 \\
\text { study that was part of } \\
\text { a general } \\
\text { improvement } \\
\text { program where } \\
\text { rounds were } \\
\text { implemented showed } \\
\text { some improvement in } \\
\text { organizational culture } \\
\text { in the control } \\
\text { hospitals but none or } \\
\text { some decline in other } \\
\text { measures } \\
\text { Mixed results may } \\
\text { suggest difference in } \\
\text { implementation may } \\
\text { drive success. } \\
\text { Determinants of } \\
\text { success include } \\
\text { breath of the } \\
\text { exposure of rounds to } \\
\text { staff, characteristics } \\
\text { of the leader, } \\
\text { willingness of staff to }\end{array}$ \\
\hline
\end{tabular}




\begin{tabular}{|c|c|c|c|c|}
\hline Reference & Purpose & $\begin{array}{c}\text { Design/Site/Sampl } \\
\text { e/ } \\
\text { Limitations }\end{array}$ & $\begin{array}{c}\text { Intervention } \\
\text { / } \\
\text { Instrument }\end{array}$ & Results \\
\hline & & & & $\begin{array}{l}\text { speak up, adequacy } \\
\text { of implementation } \\
\text { and sustaining } \\
\text { structure, and the } \\
\text { specific type of } \\
\text { rounds implemented. } \\
\text { Successful } \\
\text { implementation } \\
\text { required significant } \\
\text { organizational will. } \\
\text { Leaders must be } \\
\text { actively engaged, } \\
\text { assume } \\
\text { accountability of } \\
\text { issue resolution and } \\
\text { feedback to the front } \\
\text { line. } \\
\text { Attentive listening } \\
\text { important to } \\
\text { understand the issues } \\
\text { staff present. } \\
\text { Surveillance and } \\
\text { control rather than } \\
\text { inquiry and support } \\
\text { as leaders must be } \\
\text { able to connect with } \\
\text { staff. } \\
\text { Potential imitations } \\
\text { of rounds identified: } \\
\text { Medical errors and } \\
\text { near misses, } \\
\text { contentious } \\
\text { communication, } \\
\text { interdisciplinary } \\
\text { communication } \\
\text { challenges, care } \\
\text { delivery issues ie } \\
\text { electronic } \\
\text { information, and staff } \\
\text { education are less }\end{array}$ \\
\hline
\end{tabular}




\begin{tabular}{|c|c|c|c|c|}
\hline Reference & Purpose & $\begin{array}{c}\text { Design/Site/Sampl } \\
\text { e/ } \\
\text { Limitations }\end{array}$ & $\begin{array}{c}\text { Intervention } \\
\text { / } \\
\text { Instrument }\end{array}$ & Results \\
\hline & & & & $\begin{array}{l}\text { freq-untly discussed } \\
\text { Leaders may hesitate } \\
\text { to address } \\
\text { infrastructure issues } \\
\text { that are costly. } \\
\text { When such issues not } \\
\text { discussed front line } \\
\text { staff may become } \\
\text { frustrated and could } \\
\text { worsen the climate } \\
\text { and negate attention } \\
\text { to patient safety. }\end{array}$ \\
\hline $\begin{array}{l}\text { (Morello et } \\
\text { al., 2013) } \\
\text { Strategies for } \\
\text { Improving } \\
\text { patient safety } \\
\text { culture in } \\
\text { hospitals: a } \\
\text { systematic } \\
\text { Review }\end{array}$ & $\begin{array}{l}\text { To determine } \\
\text { the } \\
\text { effectiveness } \\
\text { of patient } \\
\text { safety culture } \\
\text { strategies to } \\
\text { improve } \\
\text { hospital patient } \\
\text { safety culture } \\
\text { climate. } \\
\text { Aim: Critically } \\
\text { assess the } \\
\text { evidence for } \\
\text { the } \\
\text { effectiveness } \\
\text { of patient } \\
\text { safety climate } \\
\text { in hospitals, to } \\
\text { support } \\
\text { decision } \\
\text { making, and } \\
\text { funding } \\
\text { providers }\end{array}$ & $\begin{array}{l}\text { Systematic Review } \\
\text { 1996-2011 } \\
\text { Hospitals } \\
21 \text { studies included } \\
1 \text { cluster RCTs } \\
\text { Non RCTs } \\
7 \text { Controlled before } \\
\text { and after studies } \\
\text { Interrupted time } \\
\text { series } \\
\text { 13 Historically } \\
\text { controlled studies } \\
\text { 3/21 used mixed } \\
\text { methods } \\
\text { evaluations } \\
\text { Critical Appraisal } \\
\text { completed by } 2 \\
\text { independent } \\
\text { reviewers } \\
\text { Implementation } \\
\text { lessons and data }\end{array}$ & $\begin{array}{l}11 \text { used } \\
\text { Safety } \\
\text { Attitudes } \\
\text { Questionnair } \\
\text { e or } \\
\text { adaptation of } \\
1 \text { used Safety } \\
\text { Climate } \\
\text { Survey } \\
\text { (SAQ) } \\
2 \text { used } \\
\text { Patient } \\
\text { Safety } \\
\text { Cultures in } \\
\text { Healthcare } \\
\text { Organization } \\
\text { s } \\
4 \text { used The } \\
\text { Hospital } \\
\text { Survey on } \\
\text { Patient } \\
\text { Safety } \\
\text { Culture } \\
2 \text { used the }\end{array}$ & $\begin{array}{l}\text { Leadership } \\
\text { WalkRounds No } \\
\text { effect on safety } \\
\text { climate scores by } \\
\text { doctors and clinicians } \\
\text { but a } \\
\text { positive effect was } \\
\text { seen compared to the } \\
\text { control group } \\
\text { (p=0.02) } \\
\text { Structured } \\
\text { educational programs } \\
\text { positive effect on } \\
\text { team climate (1/6 } \\
\text { dimensions of SAQ. } \\
\text { No difference seen in } \\
\text { the baseline groups } \\
\text { Another study found } \\
\text { an effect on } 1 / 3 \\
\text { dimensions of safety } \\
\text { climate (p=<0.001) } \\
\text { Team bases } \\
\text { strategies: } \\
1 \text { no effect on climate } \\
\text { scores but there was a } \\
\text { positive effect on the }\end{array}$ \\
\hline
\end{tabular}




\begin{tabular}{|c|c|c|c|c|}
\hline Reference & Purpose & $\begin{array}{c}\text { Design/Site/Sampl } \\
\text { e/ } \\
\text { Limitations } \\
\end{array}$ & $\begin{array}{c}\text { Intervention } \\
\text { / } \\
\text { Instrument } \\
\end{array}$ & Results \\
\hline & & $\begin{array}{l}\text { from studies were } \\
\text { reviewed } \\
\text { Meta-analysis } \\
\text { could not be } \\
\text { completed due to } \\
\text { insufficient } \\
\text { homogeneity in } \\
\text { populations, } \\
\text { interventions, } \\
\text { outcome measures } \\
\text { and follow up time. } \\
\text { Limitations } \\
\text { Non-equivalent } \\
\text { control groups, use } \\
\text { of a historical } \\
\text { control group, risk } \\
\text { of selection bias, } \\
\text { small sample sizes, } \\
\text { limited follow up } \\
\text { response rates, } \\
\text { short observational } \\
\text { periods, use of post } \\
\text { hoc statistical } \\
\text { analysis for effect } \\
\text { examination. } \\
\text { Most studies did } \\
\text { not adequately } \\
\text { control for potential } \\
\text { threats of } \\
\text { bias/confounding } \\
\text { factors (threat of } \\
\text { Internal Validity) } \\
\text { Cannot generalize } \\
\text { results as 9/12 } \\
\text { studies were in a } \\
\text { single hospital or } \\
\text { clinical units. }\end{array}$ & $\begin{array}{l}\text { National } \\
\text { Health } \\
\text { Service } \\
\text { National } \\
\text { Staff Survey } \\
4 \text { studies did } \\
\text { factor } \\
\text { analysis to } \\
\text { assess } \\
\text { internal } \\
\text { consistency } \\
\text { and content } \\
\text { reliability of } \\
\text { items on the } \\
\text { tools used. } \\
\text { Strategies } \\
\text { utilized: } \\
3 \text { Leadership } \\
\text { WalkRounds } \\
2 \text { structured } \\
\text { educational } \\
\text { programs } \\
3 \text { team based } \\
5 \text { Simulation } \\
\text { based } \\
\text { training } \\
7 \text { Multi } \\
\text { faceted unit } \\
\text { based } \\
\text { programs } \\
1 \text { Multi } \\
\text { component } \\
\text { organizationa } \\
1 \\
\text { interventions }\end{array}$ & $\begin{array}{l}\text { team work climate } \\
\text { dimension ( } \mathrm{p}=<0.01 \text { ); } \\
\text { with TeamSTEPPS } \\
\text { training ther was a } \\
\text { positive trend in } \\
\text { improvement over } \\
\text { time for the } \\
\text { intervention and } \\
\text { control groups } \\
\text { (p=<0.001) no } \\
\text { differences in the } \\
\text { groups } \\
\text { Another study } \\
\text { positive effect on } \\
2 / 12 \text { dimensions } \\
\text { (frequency of } \\
\text { reporting ( } \mathrm{p}=<0.04 \text { ), } \\
\text { organizational } \\
\text { learning (p=<0.01) } \\
\text { Simulation based } \\
\text { training programs: } \\
1 \text { study No effect on } \\
\text { climate scores } \\
4 \text { other studies had } \\
\text { varying levels of } \\
\text { effectiveness } \\
\text { Multi-faceted a unit } \\
\text { based program found } \\
\text { a positive effect } \\
\text { (p=<0.05) } \\
\text { The other } 6 \text { showed } \\
\text { varying levels of } \\
\text { improgligible effect was } \\
\text { least one dimension } \\
\text { of safety climate over } \\
\text { time. }\end{array}$ \\
\hline
\end{tabular}




\begin{tabular}{|c|c|c|c|c|}
\hline Reference & Purpose & $\begin{array}{c}\text { Design/Site/Sampl } \\
\text { e/ } \\
\text { Limitations } \\
\end{array}$ & $\begin{array}{c}\text { Intervention } \\
\text { / } \\
\text { Instrument } \\
\end{array}$ & Results \\
\hline & & & & $\begin{array}{l}\text { reported on the scores } \\
6 \text { studies reported } \\
\text { qualitative data and } \\
\text { lessons learned } \\
\text { focus group } \\
\text { interviews told of } \\
\text { gaps between } \\
\text { management level } \\
\text { engagement, ward } \\
\text { practice, clinical staff } \\
\text { engagement and } \\
\text { practice change due } \\
\text { to the } \\
\text { underestimation of } \\
\text { resources needed and } \\
\text { organizational } \\
\text { support needed to } \\
\text { make a change. } \\
\text { Observational } \\
\text { analysis in one study } \\
\text { of TeamSTEPPS saw } \\
\text { an improvement in } \\
\text { team behaviors and } \\
\text { structure and process } \\
\text { of team meeting post } \\
\text { intervention. }\end{array}$ \\
\hline $\begin{array}{l}\text { (McFadden, } \\
\text { Stock, \& } \\
\text { Gowen, 2015) } \\
\text { Leadership, } \\
\text { safety climate, } \\
\text { and } \\
\text { continuous } \\
\text { quality } \\
\text { improvement: } \\
\text { Impact on } \\
\text { process } \\
\text { quality and } \\
\text { patient safety }\end{array}$ & $\begin{array}{l}\text { To present a } \\
\text { model that } \\
\text { show how } \\
\text { transformation } \\
\text { al leadership, } \\
\text { safety climate, } \\
\text { and continuous } \\
\text { quality } \\
\text { improvement } \\
\text { initiatives are } \\
\text { related to } \\
\text { object quality } \\
\text { and patient } \\
\text { safety outcome } \\
\text { measures }\end{array}$ & $\begin{array}{l}\text { Cohort-Hybrid } \\
\text { Study } \\
\text { Prospective and } \\
\text { Retrospective } \\
\text { Survey } \\
\text { methodology } \\
\text { Unit of analysis } \\
\text { Hospital } \\
\text { organization } 48 / 50 \\
\text { in the U.S., from } 5 \\
\text { regions of the U.S. } \\
\text { 371 hospitals with } \\
\text { matching to CMS }\end{array}$ & $\begin{array}{l}\text { Dependent } \\
\text { Hospital } \\
\text { acquired } \\
\text { condition } \\
\text { (HAC) and } \\
\text { Process } \\
\text { quality scores } \\
\text { (PQS) } \\
\text { Center for } \\
\text { Medicare and } \\
\text { Medicaid } \\
\text { Services } \\
\text { (CMS) } \\
\text { Hospital } \\
\text { compare } \\
\text { Data }\end{array}$ & $\begin{array}{l}59.3 \% \text { response rate } \\
\text { Hospitals with } \\
\text { multiple respondents } \\
\text { there was consensus } \\
\text { with answers no } \\
\text { statistical difference } \\
\text { with } 1 \text { or multiple } \\
\text { respondents for } 1 \\
\text { hospital } \\
\text { No difference in the } \\
\text { bed size other than } \\
\text { the } 6 \text { bed hospital } \\
\text { that was removed } \\
\text { from the sample }\end{array}$ \\
\hline
\end{tabular}




\begin{tabular}{|c|c|c|c|c|}
\hline Reference & Purpose & $\begin{array}{c}\text { Design/Site/Sampl } \\
\text { e/ } \\
\text { Limitations }\end{array}$ & $\begin{array}{c}\text { Intervention } \\
\text { / } \\
\text { Instrument }\end{array}$ & Results \\
\hline & & $\begin{array}{l}\text { data and removal of } \\
\text { a } 6 \text { bed hospital } \\
\text { decrease to } 204 \\
\text { Rural and urban } \\
\text { hospitals, no VA, } \\
\text { psychiatric, or } \\
\text { rehab } \\
\text { Sample } \\
\text { convenience } \\
\text { Hypotheses: } \\
\text { 1. Leadership } \\
\text { will be } \\
\text { positively } \\
\text { associated } \\
\text { with patient } \\
\text { safety } \\
\text { culture } \\
\text { (PSC) } \\
\text { 2. PSC will be } \\
\text { positively } \\
\text { associated } \\
\text { with CQI } \\
\text { iniatives. } \\
\text { CQI } \\
\text { initiatives } \\
\text { will be } \\
\text { negatively } \\
\text { associated } \\
\text { with } \\
\text { Hospital } \\
\text { acquired } \\
\text { will be } \\
\text { conditions } \\
\text { (HAC) rates } \\
\text { as a patient } \\
\text { safety } \\
\text { outcome } \\
\text { measure } \\
\text { CQ }\end{array}$ & $\begin{array}{l}\text { Questionnair } \\
\text { e } \\
\text { Multifactor } \\
\text { Leadership } \\
\text { Questionnair } \\
\text { e } \\
\text { Independent } \\
\text { perceptions } \\
\text { of Safety } \\
\text { Climate } \\
\text { Safety } \\
\text { Climate } \\
\text { Survey (a } \\
\text { subset of) } \\
\text { CQI: control } \\
\text { charts, } \\
\text { process } \\
\text { competitive } \\
\text { benchmarkin } \\
\text { g, quality } \\
\text { teams of } \\
\text { employees } \\
\text { Structural } \\
\text { equitation } \\
\text { modeling to } \\
\text { verify the } \\
\text { measures and } \\
\text { on the } \\
\text { hypothesized } \\
\text { relationships }\end{array}$ & $\begin{array}{l}\text { All hypothesizes } \\
\text { were supported in the } \\
\text { expected direction } \\
\text { except H3 (CQI was } \\
\text { associated with } \\
\text { higher HAC rates } \\
\text { rather than lower } \\
\text { Quality and Safety } \\
\text { are different } \\
\text { Leaders style is } \\
\text { directly related to a } \\
\text { strong PSC and is } \\
\text { directly related to } \\
\text { employees' } \\
\text { perceptions of safety } \\
\text { culture. Implies that } \\
\text { executive leadership } \\
\text { should play an active } \\
\text { role in creating PSC } \\
\text { where employees feel } \\
\text { comfortable voicing } \\
\text { their safety concerns } \\
\text { and ensuring } \\
\text { implementation of } \\
\text { quality and safety } \\
\text { practices. }\end{array}$ \\
\hline
\end{tabular}




\begin{tabular}{|c|c|c|c|c|}
\hline Reference & Purpose & $\begin{array}{c}\text { Design/Site/Sampl } \\
\text { e/ } \\
\text { Limitations }\end{array}$ & $\begin{array}{c}\text { Intervention } \\
\text { / } \\
\text { Instrument }\end{array}$ & Results \\
\hline & & $\begin{array}{l}\text { positively } \\
\text { associated } \\
\text { with process } \\
\text { quality } \\
\text { scores } \\
\text { (PQS) a } \\
\text { process } \\
\text { quality } \\
\text { measure }\end{array}$ & & \\
\hline $\begin{array}{l}\text { (Sexton et al., } \\
\text { 2017) } \\
\text { Providing } \\
\text { feedback } \\
\text { following } \\
\text { Leadership } \\
\text { WalkRounds } \\
\text { is associated } \\
\text { with better } \\
\text { patient safety } \\
\text { culture, higher } \\
\text { employee } \\
\text { engagement } \\
\text { and lower } \\
\text { burnout }\end{array}$ & $\begin{array}{l}\text { To replicate a } \\
\text { WalkRound } \\
\text { (WR) analysis } \\
\text { when the } \\
\text { Safety } \\
\text { Attitudes } \\
\text { Questionnaire } \\
\text { (SAQ) was the } \\
\text { measurement } \\
\text { tool. This } \\
\text { study will use } \\
\text { the Safety, } \\
\text { Communicat- } \\
\text { ion, } \\
\text { Operational } \\
\text { Reliability, and } \\
\text { Engagement } \\
\text { Survery } \\
\text { (SCORE) }\end{array}$ & $\begin{array}{l}\text { Cross-sectional } \\
\text { survey } \\
\text { Convenience } \\
\text { Sample of } 31 \\
\text { hospitals in } \\
\text { Michigan } \\
839 \text { work settings } \\
\text { During a } 2 \text { month } \\
\text { period as part of } \\
\text { their routine safety } \\
\text { culture assessment } \\
\text { Hypothesis: } \\
\text { Work settings with } \\
\text { higher rates of WR } \\
\text { with feedback will } \\
\text { report more } \\
\text { positive norms of } \\
\text { work-life climate }\end{array}$ & $\begin{array}{l}\text { Instrument: } \\
\text { SCORE } \\
\text { (SAQ refined } \\
\text { and } \\
\text { combined } \\
\text { with work } \\
\text { setting norms } \\
\text { of health care } \\
\text { worker } \\
\text { engagement, } \\
\text { resilience } \\
\text { (work life } \\
\text { balance), and } \\
\text { burnout }\end{array}$ & $\begin{array}{l}70.4 \% \text { response rate } \\
53 \% \text { of respondents } \\
\text { had been in their } \\
\text { specialty for at least } \\
10 \text { yrs. } \\
\text { Nurses were the } \\
\text { largest respondent } \\
\text { group ( } 27.1 \% \text { ) } \\
\text { Hypothesis was not } \\
\text { supported nor did } \\
\text { they trend in the } \\
\text { direction of other } \\
\text { positive trending of } \\
10 \text { domain scores. } \\
\text { WRs with feedback } \\
\text { indicated better } \\
\text { workplace norms of } \\
\text { improvement } \\
\text { readiness, local }\end{array}$ \\
\hline
\end{tabular}




\begin{tabular}{|c|c|c|c|c|}
\hline Reference & Purpose & $\begin{array}{c}\text { Design/Site/Sampl } \\
\text { e/ } \\
\text { Limitations } \\
\end{array}$ & $\begin{array}{c}\text { Intervention } \\
\text { / } \\
\text { Instrument }\end{array}$ & Results \\
\hline & & $\begin{array}{l}\text { and and workload. } \\
\text { Limitations: Cross- } \\
\text { sectional surveys } \\
\text { allow observations } \\
\text { and associations } \\
\text { but causal } \\
\text { relationships cannot } \\
\text { be made } \\
\text { Bias could have } \\
\text { been introduced if } \\
\text { leaders that } \\
\text { conducted WR } \\
\text { selected work } \\
\text { settings they felt } \\
\text { comfortable } \\
\text { rounding on. } \\
\text { Common method } \\
\text { bias because all } \\
\text { variables were } \\
\text { collected via } \\
\text { surveys and } \\
\text { relationships could } \\
\text { be inflated } \\
\text { Convenience } \\
\text { sample } \\
\text { Sample not } \\
\text { representative and } \\
\text { threatens external } \\
\text { validity }\end{array}$ & & $\begin{array}{l}\text { leadership, } \\
\text { teamwork, safety } \\
\text { culture, advancement, } \\
\text { growth opportunities, } \\
\text { participation in } \\
\text { decision making. }\end{array}$ \\
\hline
\end{tabular}




\section{Appendix B}

\section{Definition of Terms}

Executive Leadership: Vice President and Assistant Administrator

Patient Safety: freedom from accidental or inadvertent injury during the deliver of health care services.

Plan-Do-Study-Act (PDSA): Another name for a structured trial (a cycle) of change that includes the phases of plan, do, study, act. Plan is the planning phase; Do is when the change is tried and there is observation of what happens; Study is an analysis of the results of the trial; Act is devising next steps based on the analysis (Botwinick, Bisognano, \& Haraden, 2006)

Safety Culture/climate: "the product of individual and group values, attitudes, perceptions, competencies, and patterns of behavior that determine the commitment to, and the style and proficiency of, an organization's health and safety management. Organization's with a positive safety culture are characterized by communications founded on mutual trust, by shared perceptions of the importance of safety, and by confidence in the efficacy of preventive measures" (Sorra \& Nieva, 2004, p. 1). 


\section{Appendix C}

\section{Leadership WalkRounds ${ }^{\mathrm{TM}}$ (LW)}

Ground Rules: Decide whether to announce the time and place of rounds and agreed to by Executive Leaders and Managers

Who should conduct? Senior leaders (those above the Nurse Manager level)

How often: Min of once per week for a minimum of one year, with no cancelations (if cancelations must reschedule within the week).

Where: Patient care units, operating rooms, emergency department, radiology, pharmacy, lab

What format: a conversation with 3-5 employees and structured in various ways, hallway conversations, individual conversations, conversations with employees in a specific type function or job, conversations in the same location each week

\section{Senior Leaders Script for LW:}

We are moving to open communication and a blame free environment because we believe by doing so we can make your work environment safer for you and your patients.

We are focusing on system and not individuals.

The discussion we are having with you is confidential and for patient safety improvement, what we talk about will not go beyond this group unless you tell me there is a need for that.

I may ask general questions to help you think of areas to which the questions might apply like medication errors, miscommunication including arguments, distractions, inefficiencies, invasive treatments, falls, protocols not follow, etc.

\section{Questions to ask:}

Can you think of any events in the past few days that have length of stay to be increased? Have there been any near misses? 
Have there been any incidents lately that you can think of where a patient was harmed?

What aspects of the environment might lead to harm?

Is there anything we can do to prevent the next adverse event?

Can you think of any way the system fails you on a consistent basis?

How can leadership make it safer for you and your patients?

(Frankel, 2004) 


\section{Appendix D \\ Consent for Participating in a Nursing Research Study}

\section{Introduction:}

You are invited to participate in a research study. This study is focused on the perceptions of a culture of safety of the Leadership domain of management support for patient safety after the implementation of Leadership WalkRounds ${ }^{\mathrm{TM}}$ in a medical surgical setting. The title of this research is the perception of management support for patient safety after the implementation of Leadership WalkRounds ${ }^{\mathrm{TM}}$ : As a staff member on the medical surgical unit of 7 South you meet the inclusion criteria to participate.

My name is Janice M. Smith, a Doctoral-nursing student at West Virginia University, Morgantown, WV. The study I am conducting focuses on the perceptions of a culture of safety of medical surgical staff in their work place. The study is solely connected with the completion of my doctoral degree.

\section{Purpose:}

The purpose of this research is to explore medical surgical staff's perception of the culture of safety of the Leadership domain of management support for patient safety after the implementation of Leadership WalkRounds ${ }^{\mathrm{TM}}$ in their workplace.

\section{Procedure:}

You are being asked to complete a survey which is a 3 question instrument known as part of the Hospital Survey on Patient Safety that was developed by the Agency for Healthcare Research and Quality. The survey was modified from the 42 questions of the complete survey. The survey should take no more than 5 minutes to complete. Your participation in this survey is completely voluntary. 


\section{Risks:}

There are no risks or penalties identified with participating. Your participation/nonparticipation will have no impact on your place of employment in anyway.

\section{Withdrawal from the study:}

Your participation in this study is completely voluntary, and you may withdraw at any time.

\section{Costs:}

There are no costs to participate in this study.

\section{Benefits:}

The benefits of the study are aimed at increasing the nursing knowledge of a culture of safety in the workplace of medical surgical staff that has experienced Leadership WalkRounds ${ }^{\mathrm{TM}}$.

\section{Confidentiality:}

All responses are anonymous and no identifying information will be included. All data will be held secure by the investigator in a locked file for 3 years and then destroyed.

\section{Questions:}

If you have any questions or concerns about this research, you may contact the Chairpersons of the West Virginia University Institutional Review Board Scott Murdoch (304-282-2835), or via email smirbblue@gmail.com, Lesley Cottrell (304-692-3474) email lcottrell@hsc.wvu.edu, Rebecca Linger (304-388- 4998) Chairperson of the CAMC/West Virginia University Institutional Review Board, via email irb@ucwv.edu, the Chair of my Doctoral committee, Dr. Theresa Cowen, (304-347-1267) or via email tcowan@ hsc.wvu.edu, or me via 304-561-4446 or via email atjmsmith3@mix.wvu.edu.

\section{Consent:}

In completing the survey you are granting your consent to participate in this study and for me to 
use the data collected to analyze, publish, and present the findings of the study.

If you would like a copy of the final results of this study, a copy of the findings will be emailed to you upon request by contacting me at 304-561-4446 or email jmsmith3@ mix.wvu.edu.

All your responses are anonymous and no identifying information will be included in this study. Your assistance in this nursing research project is sincerely appreciated. 


\section{Appendix E}

Budget

\begin{tabular}{|c|c|c|}
\hline Budget Categories & Personal Fund & Organizational Contributions \\
\hline Administrative Costs & 1 DNP Student time $\$ 7192.87$ & $\begin{array}{l}1 \text { VP } \$ 2059.17 \\
2 \text { AAs } \$ 2505.00 \\
1 \text { NM } \$ 403.77 \\
1 \text { CMC } \$ 296.10 \\
24 \text { RNs } \$ 4040.10 \\
10 \text { HUCs } \$ 768.15 \\
6 \text { NAs } \$ 426.47 \\
\end{array}$ \\
\hline \multicolumn{3}{|c|}{ 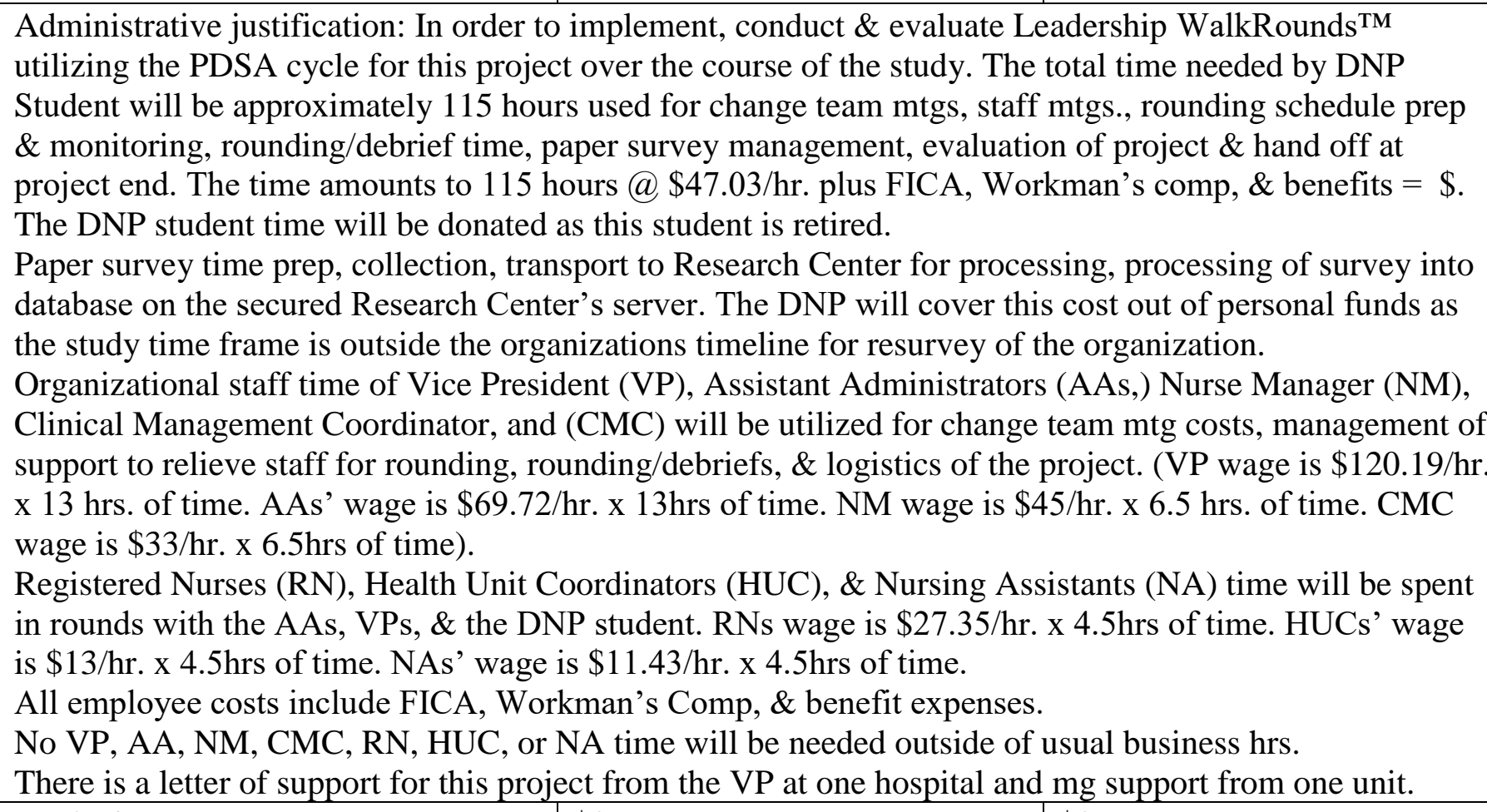 } \\
\hline Marketing & $\$ 0$ & $\$ 0$ \\
\hline \multicolumn{3}{|c|}{ Marketing justification: Marketing is within the rounding and change team structure. } \\
\hline Educational Materials & $\$ 0$ & $\$ 0$ \\
\hline \multicolumn{3}{|c|}{$\begin{array}{l}\text { Educational Materials: Educational materials are free from the Institute for Health Care Improvement } \\
\text { (IHI) and available on the web for download. Printing cost will be reflected in project supply expenses. }\end{array}$} \\
\hline Hospitality (food, room, rentals, etc.) & $\$ 0$ & $\$ 0$ \\
\hline
\end{tabular}




\begin{tabular}{|c|c|c|}
\hline Project Supplies & $\$ 35$ & $\$ 25.00$ \\
\hline \multicolumn{3}{|c|}{$\begin{array}{l}\text { Organization justification: Paper for copying as need, copy machine rental and supplies, notebook to hold } \\
\text { rounding debrief notes, pens, } \& \text { note pads if needed. These materials are already utilized by the } \\
\text { organization and available for use. } \\
\text { Personal cost includes printer paper, pens, note pad. }\end{array}$} \\
\hline Travel Expense & $\$ 282.31$ & $\$ 0$ \\
\hline \multicolumn{3}{|c|}{$\begin{array}{l}\text { Travel Justification: This cost is the DNP's travel to the organization to do this study. Rate used for } \\
\text { calculation is the } 2018 \text { IRS rate for business travel of } 54.5 \text { cents per mile. Thirty seven, } 14 \text { mile round } \\
\text { trips to the organization for this DNP to PDSA the project. Total miles } 518 \\
\text { No extra travel time will be needed for any of the organization's employees, as all time will be on their } \\
\text { work time. }\end{array}$} \\
\hline
\end{tabular}




\section{Appendix F}

\section{Hospital Survey on Patient Safety Culture: Management Support for Patient Safety}

Please indicate your agreement or disagreement with the following statements about your hospital. Mark your answer by filling in the circle.

\begin{tabular}{|lccccc|}
\hline Think about your hospital & $\begin{array}{c}\text { Strongly } \\
\text { Disagree }\end{array}$ & Disagree & Neither & Agree & $\begin{array}{c}\text { Strongly } \\
\text { Agree }\end{array}$ \\
\hline $\begin{array}{l}\text { 1. Hospital management provides a work climate that } \\
\text { promotes patient safety. }\end{array}$ & $0_{1}$ & $\mathrm{O}_{2}$ & $\mathrm{O}_{3}$ & $\mathrm{O}_{4}$ & $\mathrm{O}_{5}$ \\
\hline $\begin{array}{l}\text { 2. The actions of hospital management show that } \\
\text { patient safety is a top priority. }\end{array}$ & $\mathrm{O}_{1}$ & $\mathrm{O}_{2}$ & $\mathrm{O}_{3}$ & $\mathrm{O}_{4}$ & $\mathrm{O}_{5}$ \\
\begin{tabular}{|l} 
3. Hospital management seems interested in patient \\
safety only after an adverse event happens.
\end{tabular} & $\mathrm{O}_{1}$ & $\mathrm{O}_{2}$ & $\mathrm{O}_{3}$ & $\mathrm{O}_{4}$ & $\mathrm{O}_{5}$ \\
\hline
\end{tabular}

\section{Background Information}

This background information will help in the analysis of the survey results. Fill in one bubble.

1. How long have you worked in this hospital?

$$
\begin{array}{ll}
\text { O Less than } 1 \text { year } & \text { O } 11 \text { to } 15 \text { years } \\
\text { O } 1 \text { to } 5 \text { years } & \text { O } 16 \text { to } 20 \text { years } \\
\text { O } 6 \text { to } 10 \text { years } & \text { O } 21 \text { years or more }
\end{array}
$$

2. How long have you worked in your current hospital work area/unit?
O Less than 1 year
O 11 to 15 years
O 1 to 5 years
O 16 to 20 years
O 6 to 10 years
O 21 years or more

3. Typically, how many hours per week do you work in this hospital?
O Less than 20 hours per week
O 60 to 79 hours per week
O 20 to 39 hours per week
O 80 to 99 hours per week
O 40 to 59 hours per week
O 100 hours per week or more

4. What is your staff position in this hospital? Circle one bubble that best describes your staff position.
O Registered Nurse
O LVN/LPN
O Patient Care Assistant/Hospital Aide/Care Partner
O Unit Assistant/Clerk/Secretery

5. In your staff position, do you typically have direct interaction or contact with patients? fill in one bubble.

O YES, I typically have direct interaction or contact with patients.

O NO, I typically do NOT have direct interaction or contact with patients

6. How long have you worked in your current job catagory?
O Less than 1 year
O 11 to 15 years
O 1 to 5 years
O 16 to 20 years
O 6 to 10 years
O 21 years or more

Your Comments:

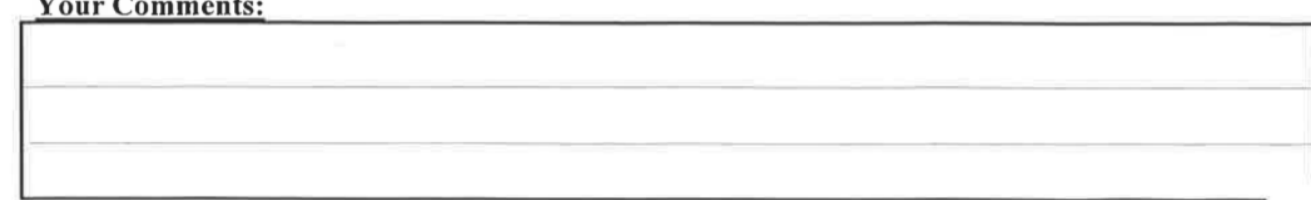

Modified from the AHRQ Hospital Survey on Patient Safety Culture ${ }^{\mathrm{TM}}$ 


\section{Appendix G}

\section{C1 Charleston Area \\ Mc. Medical Center}

GENERAL HOSPITAL

501 Morris St

PO Box 1393

Charleston, WV 25325

(304) $388-5432$

June 14, 2018

DNP Capstone Project: Leadership WalkRounds ${ }^{\mathrm{TM}}$

To whom it may concern:

Janice M. Smith has my permission to conduct her DNP Capstone Project at CAMC General Hospital on a medical surgical unit starting in 2018 running through May of 2019.

Sincerely,

MiluadD. Widuma

Michael D. Williams, MBA, FACHE

Vice President/Administrator

$\mathrm{tm}$ 


\section{Appendix F}

\section{W- WestViriginiaUniversity.}
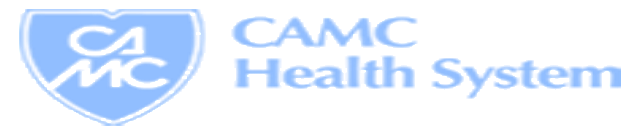

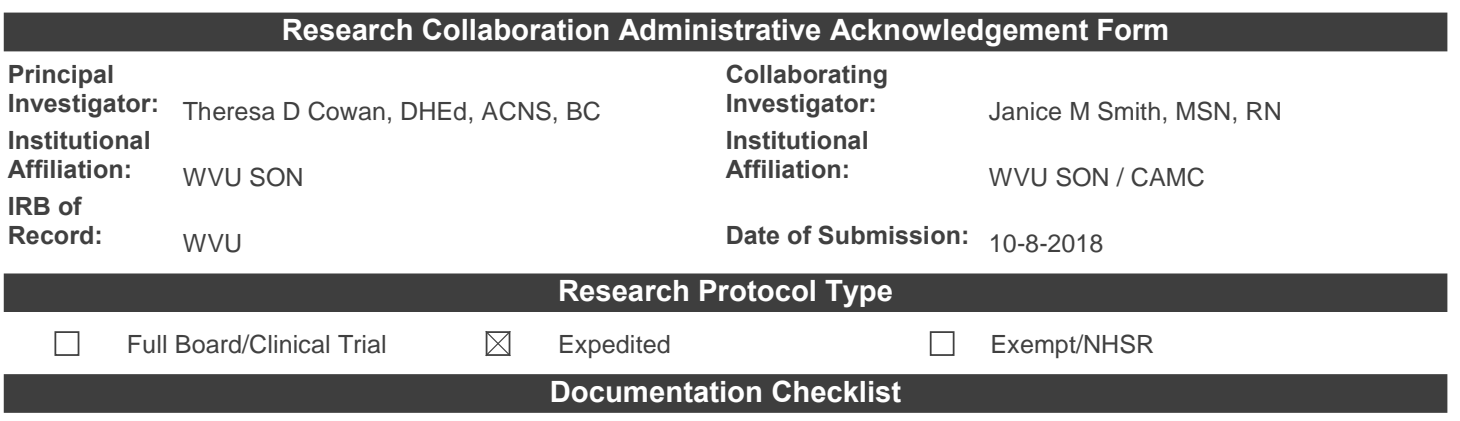

Please submit the IAA form along with the following applicable document. Select only the applicable documents.
Protocol Summary/Abstract
IRB Approved Consent Form(s)
IRB Approval/Acknowledgement Letter

Other:

Research Project Details

Title:

The Perception of Management Support for Patient Safety After the Implementation of a System Change

Description of Project (complete only if a summary or abstract is not attached):

The purpose is to implement leadership walkrounds by senior leadership on a medical surgical unit at one hospital and to improve staff perception of senior management support for patient safety. The first goal is implementation of evidenced based leadership walkrounds (see attachment) on one unit at one hospital with the aim of documenting the implementation in order to assess feasibility for replication to another unit. The second goal is to improve staff's perception of senior leadership's support for patient safety on a 35 bed medical surgical unit at a teaching nonprofit, non-government hospital in the South Atlantic Region of the U.S. The aim is to compare the perception scores after implementation of walkrounds with previous scores completed in 2017 prior to the intervention.

Additional Comments:

\section{Acknowledgment of Research Collaboration}

As documented in the IRB Authorization Agreement for IRB Protocols, "with respect to any IRB research projects by an investigator involving both institutions, either institution may be the IRB of record for IRB review, approval, and continuing oversight provided with updated information provided to the other Institution. The institution relying upon IRB review retains For WVU ORIC Use Only

Last Updated: 02/21/17 - SJS 